\title{
ANATOMI FISIOLOGI SISTEM ENDOKRIN
}

Oleh:

Setiyo Adi Nugroho. Ns. M.Kep.

Fakultas Kesehatan Universitas Nurul Jadid setiyo666@gmail.com

Sistem endokrin merupakan sistem yang unik karena terdiri dari kelompok berbagai kelenjar atau jaringan yang tersebar di seluruh tubuh. Kelenjar tubuh memiliki fungsi baik eksokrin atau endokrin. Kelenjar eksokrin, termasuk kelenjar keringat dan kelenjar lakrimal, bertanggung jawab untuk mengeluarkan zat langsung ke saluran yang mengarah ke daerah sasaran. Endokrin Istilah (endo-dalam, Crin-mensekresikan) ini menunjukkan bahwa sekresi dibentuk oleh kelenjar secara langsung masuk ke darah atau limfa sirkulasi dan perjalanan ke jaringan target, dan bukan diangkut melalui tuba atau duktus. Sekresi ini, disebut hormon, yang merupakan bahan kimia yang memicu atau mengontrol aktivitas organ, sistem, atau kelenjar lain di bagian tubuh lain (White, Duncan, \& Baumle, 2013). Hormon juga memainkan peran penting dalam mengatur proses homeostasis seperti: metabolism, tumbang, keseimbangan cairan dan elektrolit, proses reproduksi, dan siklus bangun dan tidur (Timby \& Smith, 2010).

Umumnya, hormon ini diproduksi oleh kelenjar endokrin, tetapi beberapa juga diproduksi oleh jaringan lain. mukosa Gastrointestinal (GI) menghasilkan hormon (misalnya, gastrin, enterogastrone, secretin, cholecystokinin) yang penting dalam proses pencernaan; ginjal menghasilkan erythropoietin, suatu hormon yang merangsang sumsum tulang untuk memproduksi sel darah merah; dan sel-sel darah putih memproduksi sitokin (protein menyerupai hormon) yang aktif berpartisipasi dalam respon inflamasi dan kekebalan tubuh. Sistem kekebalan tubuh dan sistem saraf memiliki hubungan yang unik dengan sistem endokrin. Porth \& Matfin, (2009) menyampaikan bahan kimia seperti neurotransmitter (misalnya, epinefrin) yang dirilis oleh Sistem saraf, juga dapat berfungsi sebagai hormon bila diperlukan. Sistem kekebalan tubuh merespon pengenalan asing agen dengan cara pembawa pesan kimiawi (sitokin), yang berupa protein menyerupai hormon, dan diatur adrenal kortikosteroid hormon (Smeltzer, Hinkle, Bare, \& Cheever, 2010)

Saraf dan sistem endokrin bertindak bersama-sama untuk mengkoordinasikan fungsi semua sistem tubuh. Ingat bahwa sistem saraf bekerja melalui impuls saraf (potensial aksi) yang dilakukan di sepanjang akson neuron. Pada sinaps, impuls saraf memicu pelepasan mediator (utusan) molekul yang disebut neurotransmitter. Sistem endokrin juga mengontrol aktivitas tubuh dengan melepaskan mediator, yang disebut hormon, tetapi alat kontrol dari dua sistem yang sangat berbeda. Tanggapan dari sistem endokrin sering lebih lambat daripada respon sistem saraf; meskipun beberapa hormon bertindak dalam hitungan detik, sebagian besar berlangsung beberapa menit atau lebih untuk menghasilkan sebuah respon. Efek dari sistem aktivasi saraf umumnya lebih singkat dibandingkan sistem endokrin. Sistem saraf bekerja pada otot-otot dan kelenjar tertentu. Pengaruh sistem endokrin jauh lebih luas; membantu mengatur hampir semua jenis sel tubuh. Kami juga akan memiliki beberapa kesempatan untuk melihat bagaimana sistem saraf dan endokrin berfungsi bersama-sama sebagai 
interlocking "supersystem." Misalnya, bagian-bagian tertentu dari sistem saraf merangsang atau menghambat pelepasan hormon oleh sistem endokrin (Tortora \& Derrickson, 2014).

\begin{tabular}{|c|c|c|}
\hline CHARACTERISTIC & NERVOUS SYSTEM & ENDOCRINE SYSTEM \\
\hline Mediator molecules & $\begin{array}{l}\text { Neurotransmitters released locally in } \\
\text { response to nerve impulses. }\end{array}$ & $\begin{array}{l}\text { Hormones delivered to tissues throughout body } \\
\text { by blood. }\end{array}$ \\
\hline Site of mediator action & $\begin{array}{l}\text { Close to site of release, at synapse; binds to } \\
\text { receptors in postsynaptic membrane. }\end{array}$ & $\begin{array}{l}\text { Far from site of release (usually); binds to } \\
\text { receptors on or in target cells. }\end{array}$ \\
\hline Types of target cells & $\begin{array}{l}\text { Muscle (smooth, cardiac, and skeletal) cells, } \\
\text { gland cells, other neurons. }\end{array}$ & Cells throughout body. \\
\hline Time to onset of action & $\begin{array}{l}\text { Typically within milliseconds (thousandths } \\
\text { of a second). }\end{array}$ & Seconds to hours or days. \\
\hline Duration of action & Generally briefer (milliseconds). & Generally longer (seconds to days). \\
\hline
\end{tabular}

Sebagian besar hormon kelenjar endokrin dikontrol oleh kelenjar hipofisis dan mekanisme feedback. Tingkat hormon dalam darah diatur oleh mekanisme homeostasis disebut negatif feedback. Jika kadar hormone dalam darah di bawah normal, negatif feedback merespon kelenjar endokrin tertentu untuk menghasilkan lebih banyak hormon, yang ketika naik ke tingkat yang normal menyebabkan penurunan produksi Mekanisme Positive feedback juga terjadi dalam sistem endokrin. Dalam Positive feedback, kenaikan tingkat satu hormon akan memicu pelepasan hormon lain. Hal ini terjadi selama siklus menstruasi wanita.(White et al., 2013).

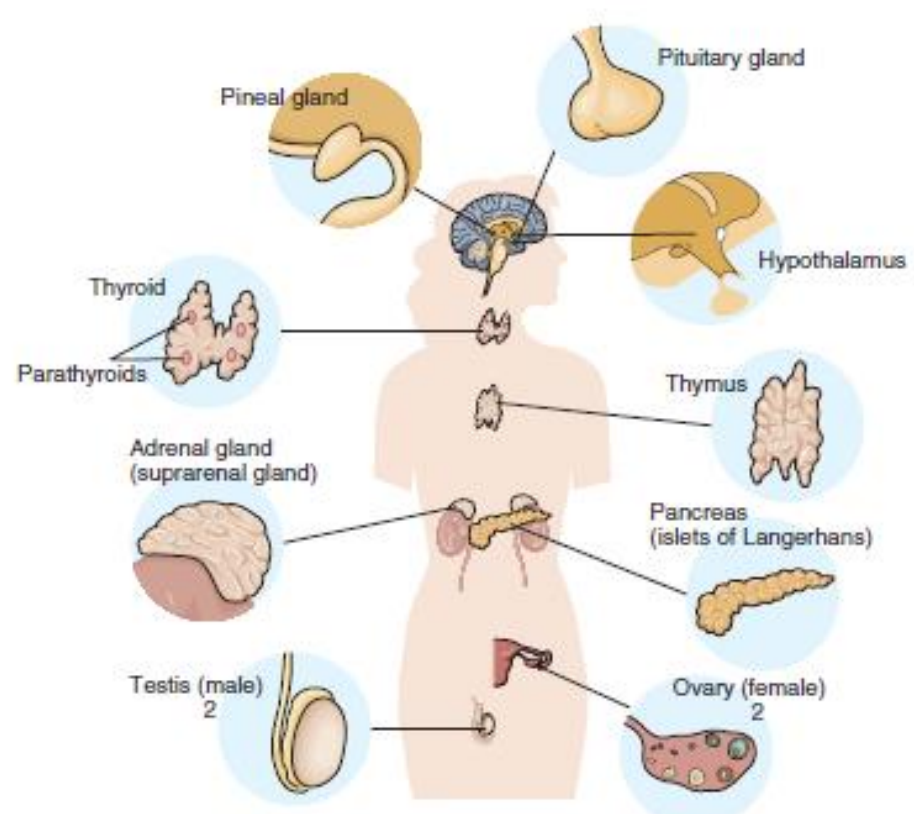

FigURE 29-1 Structures of the endocrine system.
Sistem endokrin terdiri dari hipofisis, hipotalamus, tiroid, paratiroid, pankreas, adrenal, timus, ovarium, dan testis. Sistem endokrin tidak semudah seperti sistem tubuh yang lain. Ketika membahas ketidakseimbangan sistem endokrin, seringkali adanya variasi yaitu meningkat atau menurun (misalnya, hipertiroidisme dengan hipotiroidisme) (Daniels \& Nicoll, 2012).

sebagian besar hormon yang diperlukan dalam jumlah yang sangat kecil, tingkat sirkulasi biasanya rendah. Kelenjar endokrin termasuk hipofisis, tiroid, paratiroid, adrenal, dan kelenjar pineal. Selain itu, beberapa organ dan jaringan tidak eksklusif diklasifikasikan sebagai kelenjar endokrin tapi mengandung sel-sel yang mengeluarkan hormon. ini termasuk hipotalamus, timus, pankreas, ovarium, testis, ginjal, lambung, jantung, usus kecil, kulit, jantung, jaringan adiposa, dan plasenta. Secara bersama-sama, semua kelenjar endokrin dan 
Sel-sel yang mensekresi hormon merupakan sistem endokrin (Tortora \& Derrickson, 2014).

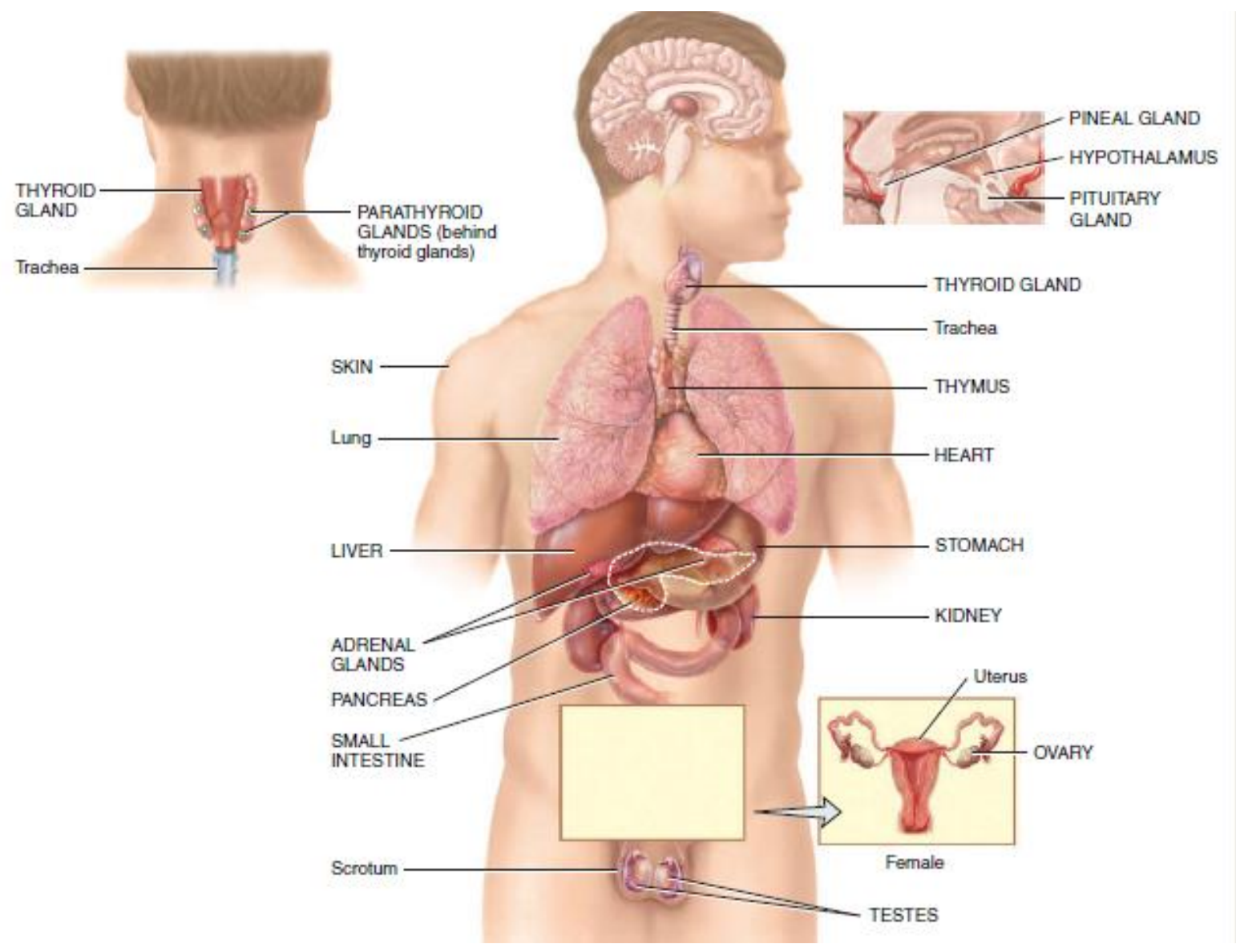

Secara umum Fungsi hormone (Tortora \& Derrickson, 2014)

1. Membantu mengatur:

a. Komposisi kimia dan volume cairan intersisial

b. Metabolism dan keseimbangan energy

c. Kontraksi otot halus dan jantung

d. Sekresi kelenjar

e. Aktivitas sistem kekebalan tubuh

2. Control tumbuh dan kembang

3. Pengontrol sistem reproduksi

4. Membantu membentuk ritme sirkandian 


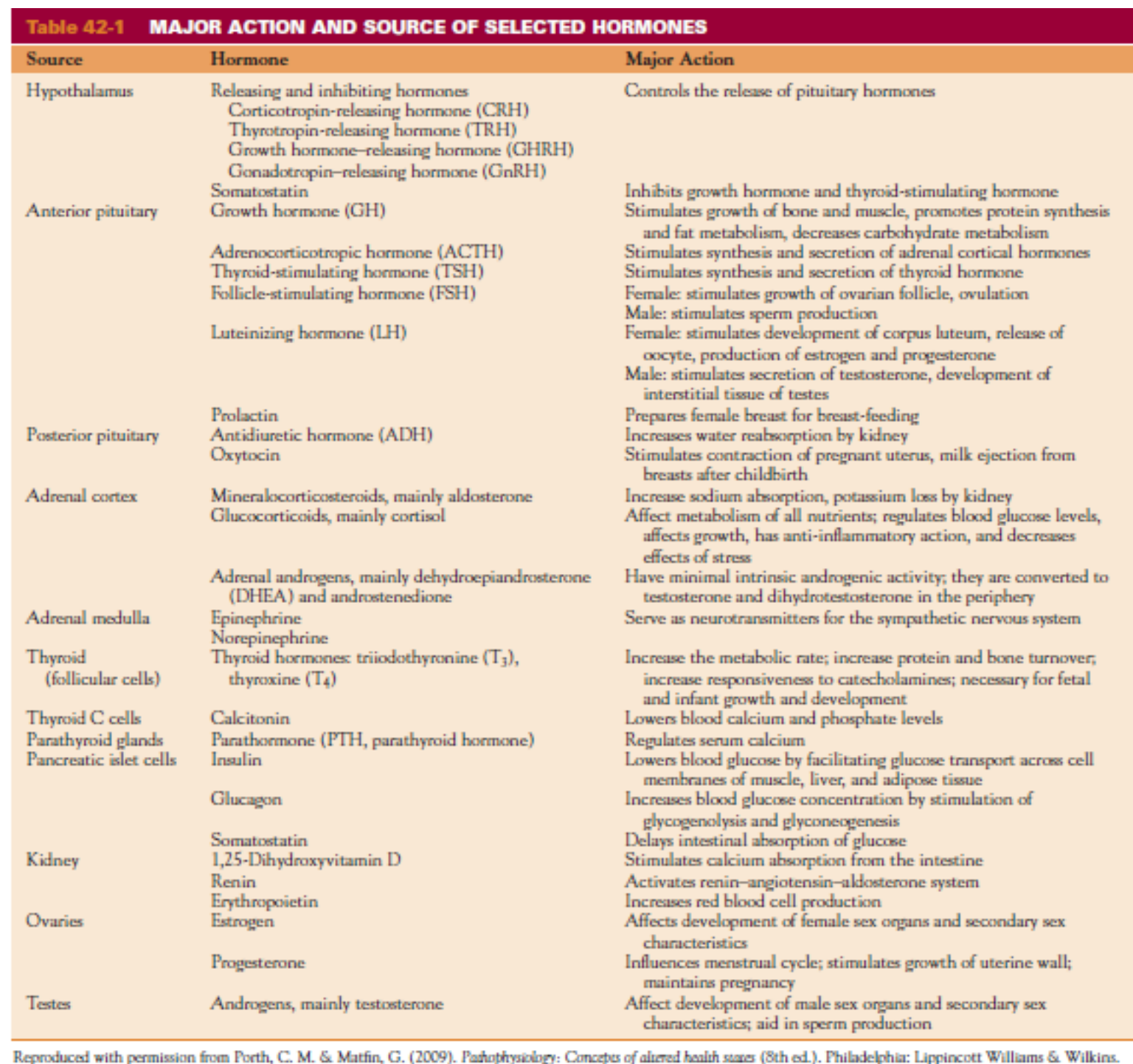

Hormone membantu mengatur fungsi organ bersama sistem syaraf. Sistem regulasi ganda ini, dimana sistem syaraf lebih cepat mempengaruhi organ dibanding sistem hormone. Sehingga menghasilkan control yang tepat bagi fungsi tubuh. Kelenjar-kelenjar endokrin terdiri dari sel sekretori disusun dalam cluster disebut acini. Tidak ada salurannya tersendiri, namun kelenjar memiliki yang kaya akan suplay darah sehingga hasil produk hormone bisa masuk melalui pembuluh darah dengan cepat. Dalam keadaan fisiologis yang sehat, konsentrasi hormone dalam aliran darah dipertahankan pada tingkat relative konstan. Negative feedback /umpang balik negative adalah mekanisme untuk mengatur konsentrasi hormone dalam darah. ketika konsentrasi hormone meningkat, produksi hormone akan dihambat. Sebaliknya, ketika konsentrasi hormone berkurang, maka produksi hormone akan lebih ditingkatkan. Hormone pada umumnya diangkut dalam cairan tubuh, dan jumlah hormone tertentu yang bersikulasi pada tubuh maka akan disesuaikan (Smeltzer et al., 2010).

\section{Aktivitas Hormon}

\section{a. Peran reseptor hormone}

Walaupun hormon beredar ke seluruh tubuh dalam darah, hal itu hanya memberikan efek sel target yang spesifik. Hormon, seperti neurotransmitter, mempengaruhi sel 
target mereka dengan mengikat kimia reseptor protein yang spesifik. Hanya sel target untuk diberikan hormon memiliki reseptor yang mengikat dan mengenali hormon. Sebagai contoh, thyroid-stimulating hormone (TSH) mengikat reseptor pada sel-sel kelenjar tiroid, tetapi tidak mengikat sel-sel ovarium karena sel-sel ovarium tidak memiliki reseptor TSH. Reseptor, seperti protein seluler lainnya, yang terus-menerus disintesis dan rusak. Umumnya, sel target memiliki 2000-100.000 reseptor untuk hormon tertentu. Jika hormon yang ada lebih, jumlah reseptor sel target dapat menurun yang disebut efek down-regulasi. Misalnya, ketika tertentu selsel testis yang terkena konsentrasi tinggi luteinizing hormone ( $\mathrm{LH})$, jumlah reseptor LH menurun. Downregulation membuat sel target kurang sensitif terhadap hormon. Sebaliknya, ketika hormon kekurangan, jumlah reseptor mungkin meningkat. Fenomena ini, yang dikenal sebagai up-regulasi, membuat Target sel lebih sensitif terhadap hormon.

Hormon sintetis yang memblokir reseptor hormon bisa sebagai obat. Sebagai contoh, RU486 (mifepristone), yang digunakan untuk menginduksi aborsi, mengikat reseptor progesteron (hormon seks wanita) dan mencegah progesteron dari mengerahkan efek normal, dalam hal ini mempersiapkan lapisan rahim untuk implantasi. Ketika RU486 diberikan kepada wanita hamil, kondisi rahim yang dibutuhkan untuk memelihara suatu embrio tidak dipertahankan, perkembangan embrio berhenti, dan embrio terkelupas bersama dengan lapisan rahim. contoh ini menggambarkan prinsip endokrin yang penting: Jika hormon dicegah dari berinteraksi dengan reseptornya, hormon tidak dapat melakukan fungsi normal.

\section{b. Sirkulasi dan hormone local}

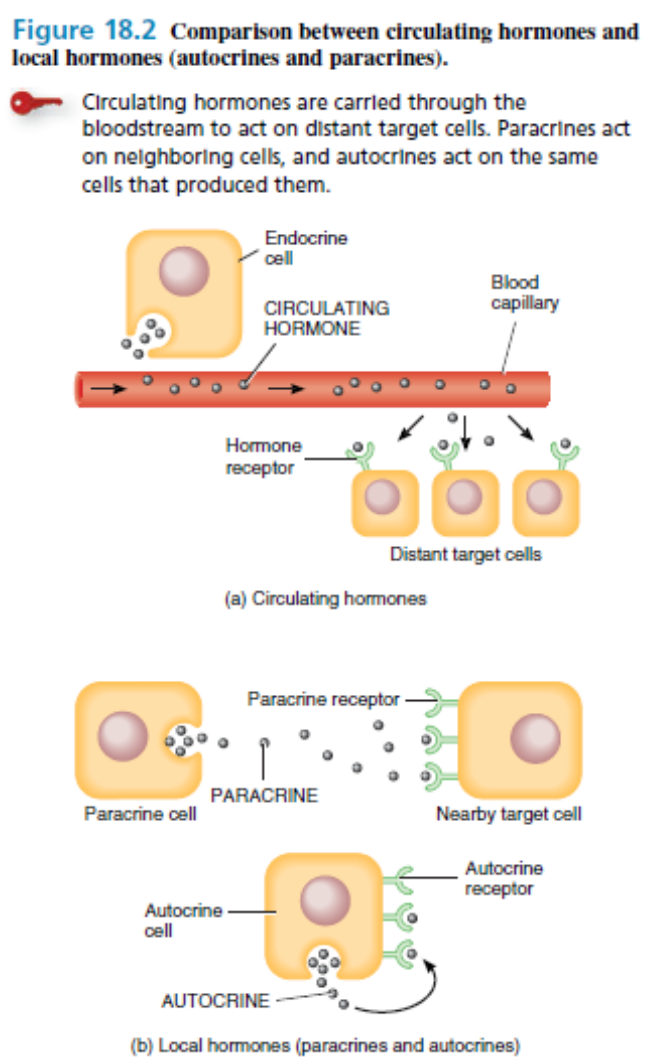

Sebagian besar circulating hormon endokrin beredar dari sel-sel sekretori menuju cairan interstitial dan kemudian ke dalam darah. Hormon lain, disebut local hormon, bertindak secara lokal pada sel tetangga atau pada sel yang sama ataupun yang disekresikan mereka tanpa terlebih dahulu memasuki aliran darah. local hormone yang bekerja pada sel-sel tetangga disebut paracrines dan mereka yang bekerja pada sel yang sama yang dikeluarkan mereka disebut autocrines. Salah satu contoh dari hormon lokal adalah interleukin-2 (IL-2), yang dilepaskan oleh sel $\mathrm{T}$ helper (sejenis sel darah putih) selama respon imun. IL-2 membantu mengaktifkan sel-sel kekebalan tubuh lain di dekatnya, sebuah efek parakrin.

Tetapi juga bertindak sebagai autokrin dengan merangsang sel yang sama yang 
dirilis untuk berkembang biak. Tindakan ini menghasilkan lebih banyak pembantu Sel $\mathrm{T}$ yang dapat mengeluarkan lebih banyak IL-2 dan dengan demikian memperkuat respon imun. Contoh lain dari hormon lokal gas nitric oxide (NO), yang dilepaskan oleh sel endotel yang melapisi pembuluh darah. NO menyebabkan relaksasi dari serat otot di dekatnya halus dalam pembuluh darah, yang pada gilirannya menyebabkan vasodilatasi (kenaikan diameter pembuluh darah). Efek dari berbagai vasodilatasi tersebut dari penurunan tekanan darah ke ereksi penis di lakilaki. Obat Viagra (sildenafil) meningkatkan efek merangsang oleh nitrit oksida dalam penis.

Local hormone biasanya tidak aktif dengan cepat; beredar hormon dapat berlamalama dalam darah dan memberi efek mereka untuk beberapa menit atau kadangkadang selama beberapa jam. Pada waktu, hormon beredar mengalami inaktivasi oleh hati dan diekskresikan oleh ginjal. Di kasus ginjal atau gagal hati, tingkat berlebihan hormon dapat bertambah dalam darah.

\section{c. Klasifikasi kimia hormone}

Secara kimia, hormon dapat dibagi menjadi dua kelas secara luas: hormon yang larut dalam lemak (Lipid-Soluble Hormones), dan hormone yang larut dalam air (WaterSoluble Hormones). Klasifikasi kimia ini juga berguna secara fungsional, karena dua kelas mengakibatkan efek mereka berbeda.

1) Larut dalam lemak

Hormon yang larut dalam lemak termasuk hormon steroid, tiroid hormon, dan nitric oxide.

a) Hormon steroid yang berasal dari kolesterol. setiap steroid Hormon ini unik karena adanya bahan kimia yang berbeda kelompok yang melekat di berbagai tempat di empat cincin pada inti strukturnya. Perbedaan kecil memungkinkan untuk keragaman besar fungsi.

b) Dua hormon tiroid (T3 dan T4) disintesis dengan menghubungkan yodium ke amino acid tyrosine. Adanya dua cincin benzena dalam T3 atau T4 molekul membuat molekul molekul sangat larut lemak

c) gas nitric oxide (NO) merupakan sebuah hormon dan neurotransmiter. Sintesis biasanya dikatalisis oleh enzim nitric oxide synthase.

2) Larut dalam air

Hormon yang larut dalam air termasuk amine hormones, peptide and protein hormones, and eicosanoid hormones.

a) amine hormones disintesis oleh decarboxylating (menghilangkan molekul CO2) dan sebaliknya memodifikasi asam amino tertentu. Mereka disebut amina karena mereka mempertahankan gugus amino (-NH3). Katekolamin-epinefrin, norepinefrin, dan dopamin, disintesis dengan memodifikasi tirosin asam amino. Histamin disintesis dari amino histidin asam oleh sel mast dan trombosit. serotonin dan melatonin yang berasal dari triptofan.

b) Peptide hormones and protein hormones yang asam aminonya polimer. Hormon peptida yang lebih kecil terdiri dari rantai 3-49 asam amino; 
hormon protein yang lebih besar termasuk 50 untuk 200 asam amino. Contoh hormon peptida yang antidiuretik hormon dan oksitosin; hormon protein dilengkapi pada manusia yaitu hormon pertumbuhan dan insulin. Beberapa hormon protein, seperti thyroid-stimulating hormone, telah terpasang kelompok karbohidrat dan karenanya glikoprotein hormon.

c) eicosanoid hormones yang berasal dari asam arakidonat, yang 20-karbon Asam lemak. Dua jenis utama dari eikosanoid merupakan prostaglandin (PG) dan leukotrien (LTs). eikosanoid adalah hormon lokal yang penting, dan mereka dapat bertindak sebagai yang hormon bersirkulasi juga.

\begin{tabular}{|c|c|c|}
\hline \multicolumn{3}{|c|}{ Summary of Hormones by Chemical Class } \\
\hline CHEMICAL CLASS & HORMONES & SITE OF SECRETION \\
\hline \multicolumn{3}{|l|}{ LIPID-SOLUBLE } \\
\hline \multirow{4}{*}{ Steroid hormones } & Aldosterone, cortisol, androgens. & Adrenal cortex. \\
\hline & Calcitriol. & Kidneys. \\
\hline & Testosterone. & Testes. \\
\hline & Estrogens, progesterone. & Ovaries. \\
\hline \multirow{2}{*}{ Thyroid hormones } & \multirow[t]{2}{*}{$\mathrm{T}_{3}$ (triiodothyronine), $\mathrm{T}_{4}$ (thyroxine). } & \multirow[t]{2}{*}{ Thyroid gland (follicular cells). } \\
\hline & & \\
\hline Gas & Nitric oxide (NO). & Endothelial cells lining blood vessels. \\
\hline \multicolumn{3}{|l|}{ WATER-SOLUBLE } \\
\hline \multirow{4}{*}{ Amines } & Epinephrine, norepinephrine (catecholarnines). & Adrenal medulla. \\
\hline & Melatonin. & Pineal gland. \\
\hline & Histamine. & Mast cells in connective tissues. \\
\hline & Serotonin. & Platelets in blood. \\
\hline \multirow{3}{*}{$\begin{array}{l}\text { Peptides and proteins } \\
\text { Glutamine L_Isoleucine } \\
\text { Asparagine }\end{array}$} & All hypothalamic releasing and inhibiting hormones. & Hypothalamus. \\
\hline & Oxytocin, antidiuretic hormone. & Posterior pituitary. \\
\hline & $\begin{array}{l}\text { Human growth hormone, thyroid-stimulating } \\
\text { hormone, adrenocorticotropic hormone, follicle- } \\
\text { stimulating hormone, luteinizing hormone, prolactin, } \\
\text { melanocyte-stimulating hormone. }\end{array}$ & Anterior pituitary. \\
\hline \multirow{6}{*}{ Leucine } & Insulin, glucagon, somatostatin, pancreatic polypeptide. & Pancreas. \\
\hline & Parathyroid hormone. & Parathyroid glands. \\
\hline & Calcitonin. & Thyroid gland (parafollicular cells). \\
\hline & $\begin{array}{l}\text { Gastrin, secretin, cholecystokinin, GIP } \\
\text { (glucose-dependent insulinotropic peptide). }\end{array}$ & $\begin{array}{l}\text { Stomach and small intestine (enteroendocrine } \\
\text { cells). }\end{array}$ \\
\hline & Erythropoietin. & Kidneys. \\
\hline & Leptin. & Adipose tissue. \\
\hline Eicosanoids & Prostaglandins, leukotrienes. & All cells except red blood cells. \\
\hline
\end{tabular}

\section{d. Transport hormone dalam darah}

Sebagian besar molekul hormon yang larut dalam air beredar di plasma darah "bebas" (tidak terikat dengan molekul lain), tetapi kebanyakan molekul hormon larut-lemak terikat dengan Protein transportasi. Protein transportasi, yang disintesis oleh

Sel-sel di hati, memiliki tiga fungsi:

1) Protein transportasi membuat hormon larut-lemak untuk sementara larut dalam air,

sehingga meningkatkan kelarutannya dalam darah. 
2) menghambat lewatnya molekul hormon yang kecil melalui Mekanisme penyaringan di dalam ginjal, sehingga memperlambat laju kehilangan hormon dalam urin.

3) menyediakan cadangan hormon.

Secara umum, 0,1-10\% dari molekul hormon larut-lemak tidak terikat pada protein transportasi. Sebagian bebas ini berdifusi dari kapiler, mengikat reseptor, dan memicu tanggapan. Sebagai molekul hormon bebas meninggalkan darah dan berikatan dengan reseptor mereka, protein transportasi lepaskan yang baru untuk mengisi bebas sebagian kecil.

\section{Mekanisme Aksi Hormon}

Respon terhadap hormon tergantung pada kedua hormon itu sendiri dan sel target. Berbagai sel target bereaksi berbeda terhadap hormon yang sama. Insulin, misalnya, merangsang sintesis glikogen pada sel hati dan sintesis trigliserida dalam adipose sel. Respon terhadap hormon ini tidak selalu sintesis molekul baru, seperti halnya insulin. hormonal lainnya efek termasuk mengubah permeabilitas membran plasma, stimulasi transport zat yang kedalam atau keluar dari target sel, mengubah laju reaksi metabolisme tertentu, atau menyebabkan kontraksi otot polos atau otot jantung. Pada bagian, efek ini bervariasi hormon yang mungkin karena satu hormon dapat menggerakkan beberapa tanggapan seluler yang berbeda.

Namun, hormon harus terlebih dahulu "mengumumkan kedatangannya" ke target sel dengan mengikat reseptor. Reseptor untuk lipidsolublehormon merupakan terletak di dalam sel target. Reseptor untuk hormon yang larut dalam air adalah bagian dari membran

plasma dari sel target.

\section{a. Aksi hormone larut lemak}

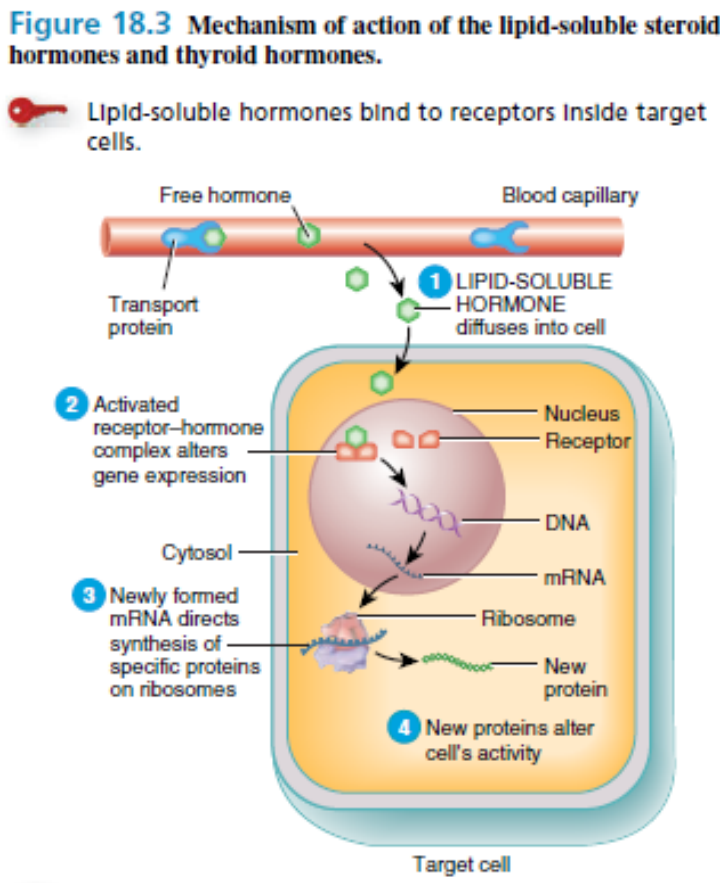

(1) Sebuah molekul hormone larut lemak yang bebas berdifusi dari darah melalui cairan intersisiel dan melalui lipid bilayer (lapisan ganda) dari membrane plasma kedalam sel

(2) Jika sel adalah sel target, hormon mengikat dan mengaktivasi reseptor terletak di sitosol atau nucleus. mengaktifkan reseptor-hormon yang kompleks kemudian mengubah ekspresi gen: Hal ini membuat gen yang spesifik dari DNA nuklir menjadi aktif atau tidak aktif.

(3) Karena DNA ditranskripsi, 
messenger RNA (mRNA) membentuk yang baru, meninggalkan nukleus, dan memasuki sitosol. Di sana, hal itu mesintesis protein baru, sering kali suatu enzim, di ribosom.

(4) Protein baru mengubah aktivitas sel dan menyebabkan respon tipikal hormon.

\section{b. Aksi hormone larut air}

Karena amine, peptida, protein, dan hormon eicosanoid merupakan tidak lemaklarut, mereka tidak dapat menyebar melalui lapisan ganda lipid membran plasma dan mengikat reseptor di sel target. Sebaliknya, hormon yang larut dalam air berikatan dengan reseptor yang menonjol dari permukaan sel target. Reseptor merupakan transmembran bagian integral protein dalam membran plasma. Ketika larut dalam air hormon berikatan dengan reseptornya di permukaan luar dari membran plasma, ia bertindak sebagai Messenger pertama. Messenger pertama (Hormon) kemudian menyebabkan produksi messenger kedua di dalam sel, di mana hormon spesifik stimulasi berlangsung. Salah satu second messenger yang sering adalah AMP siklik (cAMP). neurotransmiter, neuropeptida, dan beberapa transduksi sensori mekanisme juga bertindak melalui

Figure 18.4 Mechanism of action of the water-soluble hormones (amines, peptides, proteins, and eicosanoids).

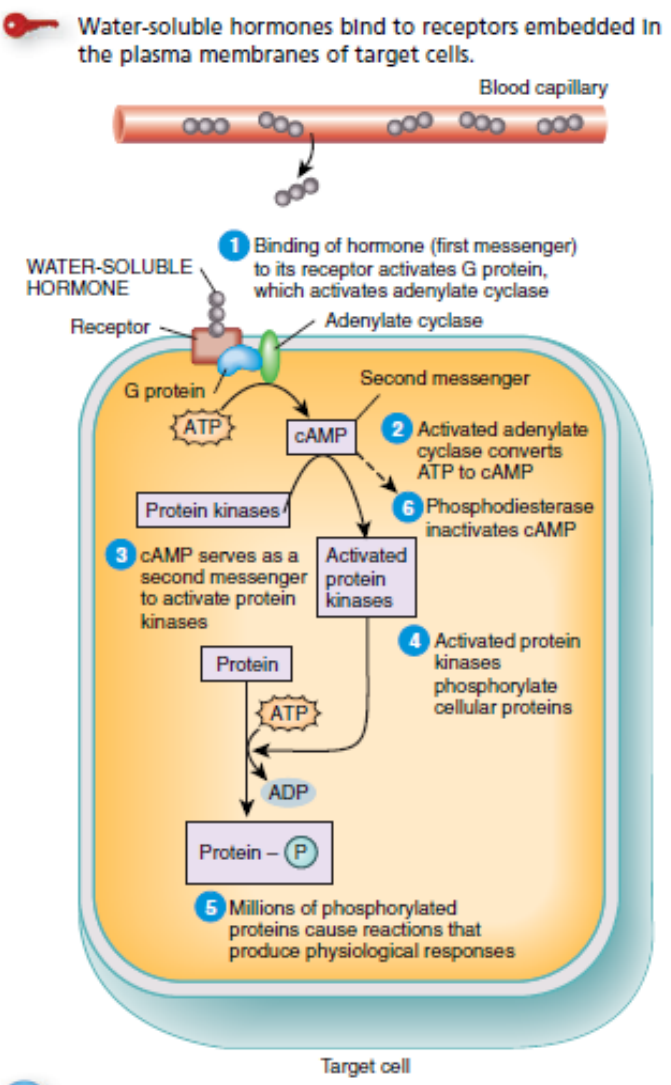

Sistem second messenger.

(1) Hormon larut dalam air (messenger pertama) berdifusi dari darah melalui cairan interstitial dan kemudian mengikat reseptor pada permukaan bagian luar membran plasma target sel. Kompleks hormon-reseptor mengaktifkan membran protein yang disebut protein G. Protein G yang mengaktifkan pada gilirannya mengaktifkan adenylate cyclase.

(2) Adenylate cyclase mengubah ATP menjadi AMP cyclic (cAMP). Karena aktif enzim site di atas permukaan bagian dalam dari membran plasma, reaksi tersebut terjadi di sitosol dari sel.

(3) Cyclic AMP (mesegger kedua) mengaktifkan satu atau lebih protein kinase, yang mungkin bebas dalam

sitosol atau terikat pada membran plasma. Sebuah protein kinase adalah enzim yang phosphorylates (gugus fosfat) protein seluler lainnya (seperti enzim). Donor fosfat grup adalah ATP, yang diubah menjadi ADP. 
(4) Activated protein kinase memfosforilasi satu atau lebih sel protein. Fosforilasi mengaktifkan beberapa protein dan menginaktivasi lain, bukan seperti menyalakan sebuah tombol aktif atau tidak aktif.

(5) Protein terfosforilasi pada gilirannya menyebabkan reaksi yang menghasilkan respon fisiologis tubuh. Protein kinase yang berbeda ada dalam sel target yang berbeda dan dalam organel yang berbeda dari sel target yang sama. Dengan demikian, salah satu protein kinase kekuatan memicu terjadinya sintesis glikogen, yang kedua dapat menyebabkan kerusakan dalam trigliserida, ketiga dapat meningkatkan sintesis protein, dan lain sebagainya. Seperti tercantum dalam langkah 4 , fosforilasi oleh protein kinase juga dapat menghambat protein tertentu. Sebagai contoh, beberapa kinase melepaskan epinefrin ketika berikatan sel hati menonaktifkan enzim yang diperlukan untuk glikogen sintesis.

(6) Setelah periode singkat, enzim yang disebut phosphodiesterase menginaktivasi cAMP. Dengan demikian, sel respon akan dinonaktifkan kecuali molekul hormon baru lainnya yang selanjutnya untuk mengikat reseptor dalam membran plasma.

\section{c. Interaksi Hormon}

Respon dari sel target untuk hormon tergantung pada (1) konsentrasi hormon dalam darah, (2) banyaknya reseptor hormon target sel, dan (3) pengaruh yang diberikan oleh hormon lainnya. Sebuah sel target merespon lebih keras ketika tingkat hormon naik atau ketika memiliki lebih reseptor (upregulation). Selain itu, aksi beberapa hormon pada target Sel-sel memerlukan simultan atau baru paparan terhadap hormon kedua. Pada kasus tersebut, hormon kedua dikatakan memiliki efek yang permisif. Sebagai contoh, epinefrin sendirian hanya lemah dalam merangsang lipolisis (pemecahan trigliserida), tapi ketika sejumlah kecil hormon tiroid (T3 dan T4) yang hadir, dalam jumlah yang sama epinefrin merangsang lipolisis jauh lebih kuat. Kadang-kadang hormon permisif meningkatkan jumlah dari reseptor untuk hormon lainnya, dan kadang-kadang mendorong sintesis suatu enzim yang diperlukan untuk mengekspresikan yang lain efek hormon itu.

Ketika efek dua hormon yang bekerja sama lebih besar atau lebih ekstensif daripada efek masing-masing hormon bertindak sendiri, dua hormon yang dikatakan memiliki efek sinergis. Sebagai contoh, perkembangan normal oosit dalam ovarium membutuhkan baik follicle-stimulating hormone dari hipofisis anterior dan estrogen dari ovarium. Hormon tidak saja sudah cukup. Ketika salah satu hormon menentang tindakan hormon lain, dua hormon yang dikatakan memiliki efek antagonis. Contoh dari pasangan antagonis hormon insulin, yang meningkatkan sintesis glikogen oleh sel-sel hati, dan glukagon, yang merangsang pemecahan glikogen di hati.

\section{Control sekresi hormone}

Pelepasan hormon sebagian besar terjadi dalam singkat, dengan sedikit atau bahkan tanpa sekresi. Ketika distimulasi, kelenjar endokrin akan melepaskan hormon dalam lebih sering, sehingga peningkatan konsentrasi hormon dalam darah. Dalam ketiadaan 
stimulasi,tingkat hormon darah menurun. Kontrol sekresi biasanya mencegah kelebihan atau kekurangan produksi. dari setiap hormon yang diproduksi untuk membantu mempertahankan homeostasis. Sekresi hormon diatur oleh (1) sinyal dari saraf sistem, (2) perubahan kimia dalam darah, dan (3) hormon lainnya. Sebagai contoh, impuls saraf ke medula adrenal mengatur pelepasan epinefrin; Tingkat $\mathrm{Ca} 2$ dalam darah mengatur sekresi hormon paratiroid; dan hormon dari anterior hipofisis (adrenocorticotropic hormone) merangsang pelepasan kortisol oleh korteks adrenal. Sebagian besar Sistem peraturan hormonal bekerja melalui umpan balik negatif, tetapi beberapa beroperasi melalui umpan balik positif. Sebagai contoh, selama melahirkan, hormon oksitosin merangsang kontraksi rahim, dan kontraksi rahim pada gilirannya merangsang lebih oksitosin direlease, efek umpan balik positif.

\section{Gland pituitary (hipofisis)}

Selama bertahun-tahun, kelenjar pituitari atau hipofisis disebut "master" kelenjar endokrin karena mengeluarkan beberapa hormon yang mengontrol kelenjar endokrin lainnya. Kita sekarang tahu bahwa hipofisis kelenjar itu sendiri memiliki master hipotalamus. Daerah ini kecil di otak bawah, thalamus adalah penghubung utama antara sistem saraf dan endokrin. Sel-sel dalam hipotalamus mensintesis setidaknya sembilan hormon yang berbeda, dan kelenjar pituitari mensekresi tujuh. Bersama-sama, hormon ini memainkan peran penting dalam regulasi hampir semua aspek pertumbuhan, perkembangan, metabolisme, dan homeostasis (Tortora \& Derrickson, 2014).

Kelenjar pituitari mempunyai struktur seperti kacang yang berdiameter $1-1,5 \mathrm{~cm}(0,5$ in.) terletak pada fossa hypophyseal sela tursika tulang sphenoid. Menempel di hipotalamus dengan tangkai, infundibulum dan memiliki dua bagian anatomis dan fungsional yang terpisah: hipofisis anterior dan hipofisis posterior. Hipofisis anterior (lobus anterior), juga disebut adenohypophysis, menyumbang sekitar $75 \%$ dari total berat kelenjar dan terdiri dari jaringan epitel. Hipofisis anterior terdiri dari dua bagian pada orang dewasa: distalis pars adalah bagian yang lebih besar, dan tuberalis pars bentuknya ada kantung di sekitar infundibulum. hipofisis Posterior (posterior lobus), juga disebut neurohypophysis, terdiri dari jaringan saraf. Ini juga terdiri dari dua bagian: nervosa pars, bagian bulbar yang lebih besar, dan infundibulum. ada wilayah ketiga dari kelenjar pituitari yang disebut intermedia pars atrophies, selama perkembangan janin manusia dan tidak lagi ada sebagai lobus tersendiri pada orang dewasa. Namun, beberapa sel yang bermigrasi ke bagian yang berdekatan dari hipofisis anterior.

\section{a. Hipofisis Anterior}

Hipofisis anterior atau adenohypophysis mengeluarkan hormon yang mengatur berbagai kegiatan tubuh, dari pertumbuhan reproduksi. Pelepasan hormon hipofisis anterior distimulasi dengan merilis hormon dan menekan dengan menghambat hormon dari hipotalamus. Dengan demikian, hormon hipotalamus adalah merupakan link penting antara sistem saraf dan endokrin.

\section{Sistem Portal Hypophyseal}

Hormon hipotalamus yang melepaskan atau menghambat hormon hipofisis anterior sampai di hipofisis anterior melalui sistem portal. Umumnya, darah yang mengalir dari jantung melalui arteri ke kapiler ke vena dan kembali ke jantung. Dalam sistem portal, darah yang mengalir dari satu jaringan kapiler ke vena portal, dan kemudian 
ke jaringan kapiler kedua sebelum kembali ke jantung. Nama sistem portal mengindikasikan lokasi jaringan kapiler kedua. Dalam sistem portal hypophyseal, darah yang mengalir dari kapiler di hipotalamus ke dalam pembuluh darah vena portal menuju ke kapiler hipofisis anterior.
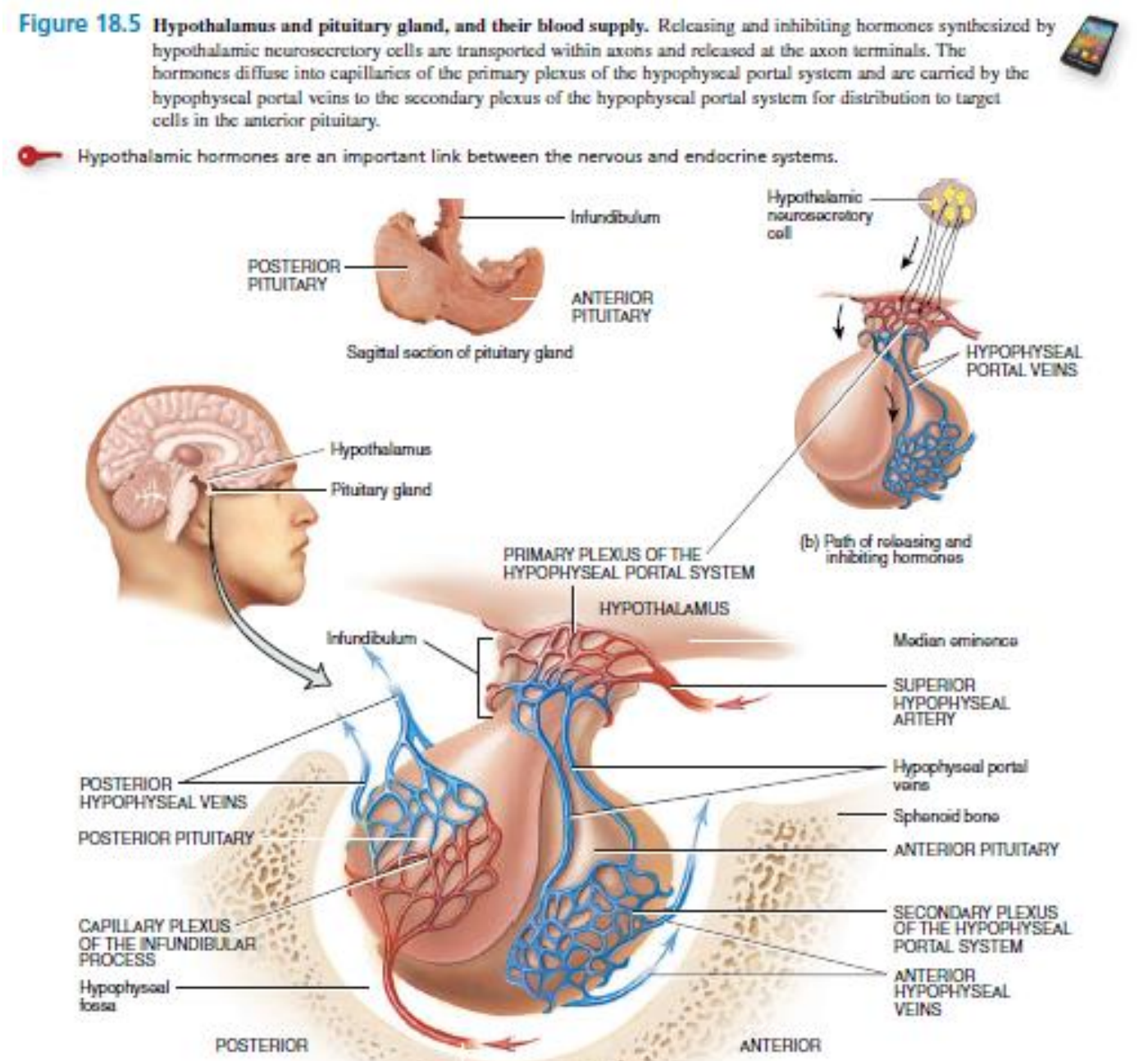

Inlarior hypophyseal artary

(a) Rolationachip of the hypothabmus to the ptutury gland
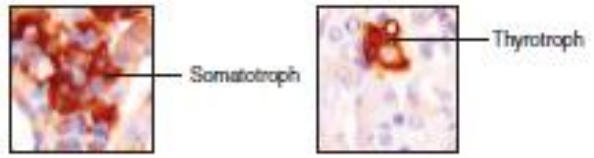
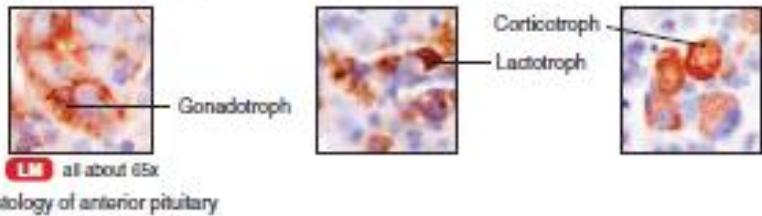

(c) Histology of anterior pitutary

Arteri hypophyseal superior, cabang arteri karotis interna, membawa darah ke hipotalamus. Di persimpangan eminensia median dari hipotalamus dan infundibulum, arteri ini terbagi menjadi jaringan kapiler disebut pleksus utama dari sistem portal hypophyseal. Dari pleksus primer, aliran darah masuk ke dalam pembuluh darah Portal hypophyseal melewati luar infundibulum. Di hipofisis anterior, vena Portal hypophyseal membagi lagi dan membentuk jaringan kapiler lain yang disebut pleksus sekunder dari sistem portal hypophyseal.

Di atas Chiasm optik adalah kelompok neuron khusus yang disebut sel neurosecretory. Mereka mensintesis hipotalamus tersebut merilis dan menghambat hormon pada tubuh sel mereka dan mengemas hormon di dalam vesikel, dimana 
sampai di terminal akson oleh transportasi aksonal. Impuls saraf merangsang vesikel mengalami eksositosis. Hormon kemudian berdifusi ke dalam pleksus utama dari sistem portal hypophyseal. Dengan Cepat, hormon hipotalamus mengalir dengan darah melalui vena portal dan ke pleksus sekunder. Jalur langsung ini memungkinkan hormon hipotalamus untuk segera bertindak pada sel hipofisis anterior, sebelum hormon dilarutkan atau hancur dalam sirkulasi umum. Hormon disekresi oleh sel-sel hipofisis anterior masuk ke dalam kapiler pleksus sekunder, dimana mengalir menuju vena hypophyseal anterior dan keluar ke sirkulasi umum. Hormon hipofisis anterior kemudian melakukan perjalanan ke menargetkan jaringan di seluruh tubuh. Hormonhormon hipofisis anterior yang bekerja pada kelenjar endokrin lain disebut hormon tropik atau tropins.

Lima jenis sel-somatotrophs hipofisis anterior, thyrotrophs, gonadotrophs, lactotrophs, dan corticotrophs-mensekresi tujuh hormon.

1) Somatotrophs mengeluarkan human Growth Hormone (hGH), juga dikenal sebagai somatotropin. human Growth Hormone pada gilirannya merangsang beberapa jaringan untuk mengeluarkan Insulinlike Growth Factors (IGFs), hormon yang merangsang pertumbuhan tubuh secara umum dan mengatur aspek metabolisme.

2) Thyrotrophs mengeluarkan thyroid-stimulating hormone (TSH), juga dikenal sebagai thyrotropin. TSH mengendalikan sekresi dan kegiatan lain dari kelenjar tiroid.

3) Gonadotrophs mengeluarkan dua gonadotropin: follicle-stimulating hormone (FSH) dan luteinizing hormone (LH). FSH dan LH baik bertindak pada gonad. Mereka menstimulasi sekresi estrogen dan progesteron dan pematangan oosit dalam ovarium, dan mereka merangsang produksi sperma dan sekresi testosteron di testis.

4) Lactotrophs mengeluarkan prolaktin (PRL), yang memulai produksi ASI di kelenjar payudara.

5) Corticotrophs mengeluarkan adrenocorticotropic hormone (ACTH), juga dikenal sebagai corticotropin, yang menstimulasi korteks adrenal untuk mensekresikan glukokortikoid seperti kortisol. Beberapa corticotrophs, sisasisa pars intermedia, juga mengeluarkan melanocyte-stimulating hormone (MSH). 


\begin{tabular}{|c|c|c|c|}
\hline \multicolumn{4}{|c|}{ Hormones of the Anterior Pituitary } \\
\hline HORMONE & SECRETED BY & $\begin{array}{l}\text { HYPOTHALAMIC RELEASING } \\
\text { HORMONE (STIMULATES SECRETION) }\end{array}$ & $\begin{array}{l}\text { HYPOTHALAMIC INHIBITING } \\
\text { HORMONE (SUPPRESSES SECRETION) }\end{array}$ \\
\hline $\begin{array}{l}\text { Human growth hormone (hGH), } \\
\text { also known as somatotropin }\end{array}$ & Somatotrophs. & $\begin{array}{l}\text { Growth hormone-releasing hormone (GHRH), } \\
\text { also known as somatocrinin. }\end{array}$ & $\begin{array}{l}\text { Growth hormone-inhibiting hormone (GHIH), } \\
\text { also known as somatostatin. }\end{array}$ \\
\hline $\begin{array}{l}\text { Thyroid-stimulating hormone } \\
\text { (TSH), also known as thyrotropin }\end{array}$ & Thyrotrophs. & Thyrotropin-releasing hormone (TRH). & Growth hormone-inhibiting hormone (GHIH). \\
\hline Follicle-stimulating hormone (FSH) & Gonadotrophs. & Gonadotropin-releasing hormone (GnRH). & - \\
\hline Luteinizing hormone (LH) & Gonadotrophs. & Gonadotropin-releasing hormone (GnRH). & - \\
\hline Prolactin (PRL) & Lactotrophs. & Prolactin-releasing hormone (PRH). ${ }^{*}$ & $\begin{array}{l}\text { Prolactin-inhibiting hormone (PIH), which is } \\
\text { dopamine. }\end{array}$ \\
\hline $\begin{array}{l}\text { Adrenocorticotropic hormone } \\
\text { (ACTH), also known as } \\
\text { corticotropin }\end{array}$ & Corticotrophs. & Corticotropin-releasing hormone (CRH). & - \\
\hline $\begin{array}{l}\text { Melanocyte-stimulating } \\
\text { hormone (MSH) }\end{array}$ & Corticotrophs. & Corticotropin-releasing hormone (CRH). & Dopamine. \\
\hline
\end{tabular}

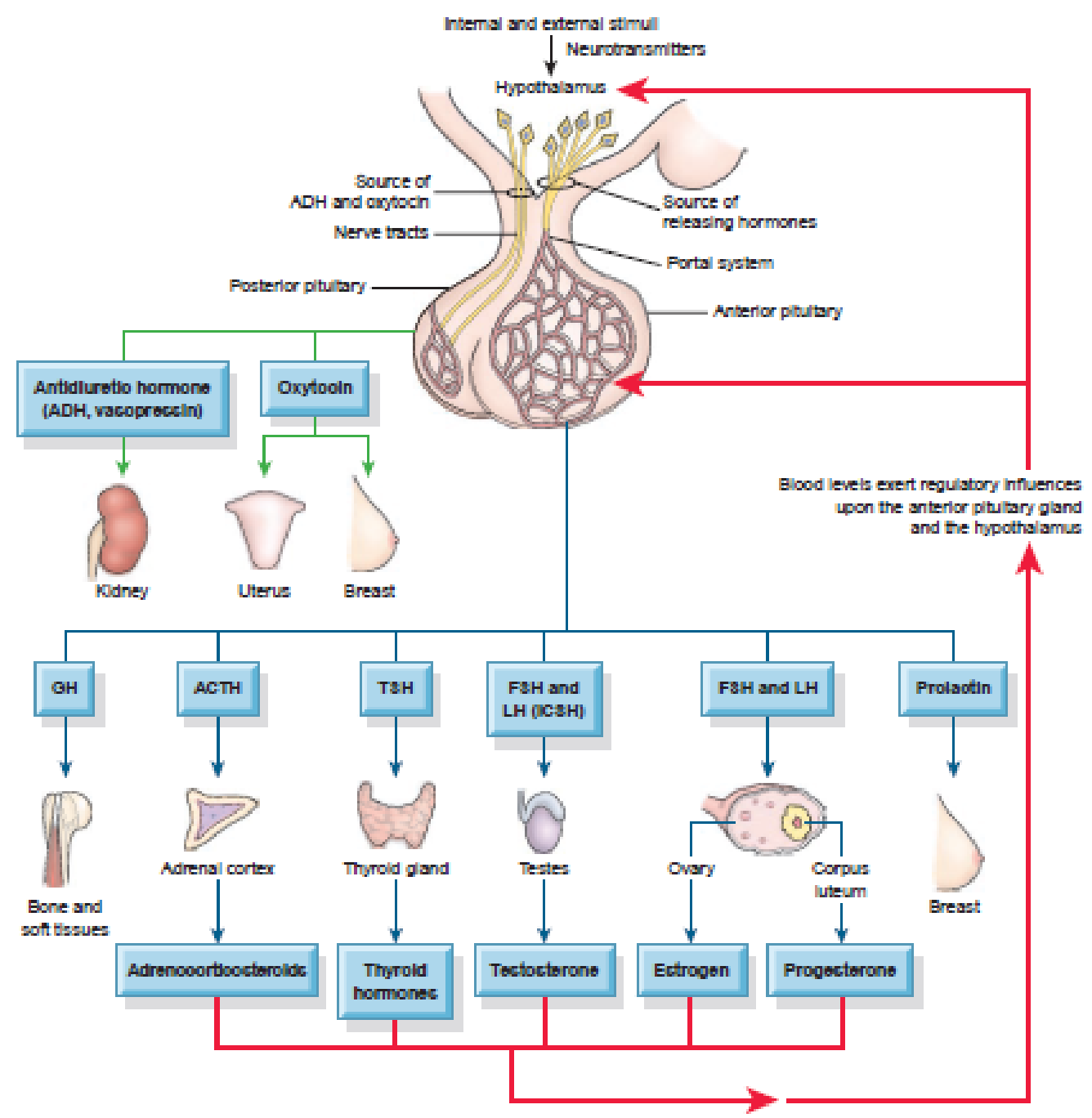

Flgure 42-2 The pituitary gland, the rolationship of the brain to pituitary action, and the hormones secroted by the anterior and posterior pituitary lobes. ACTH, adrenocorticotropic hormone; ADH, antidiurotic hormone; FSH, follicle-stimulating hormone; GH, grawth hormona; ICSH, interstitial coll-stimulating hormane; LH, lutainizing hormone; TSH, thyraid-stimulating hormone. 


\section{Pengendalian Sekresi oleh hipofisis anterior}

Figure 18.6 Negative feedback regulation of hypothalamic neurosecretory cells and anterior pituitary corticotrophs. Solid green arrows indicate stimulation of secretions; dashed red arrows indicate inhibition of secretion via negative feedback.

Cortisol secreted by the adrenal cortex suppresses secretion of CRH and ACTH.

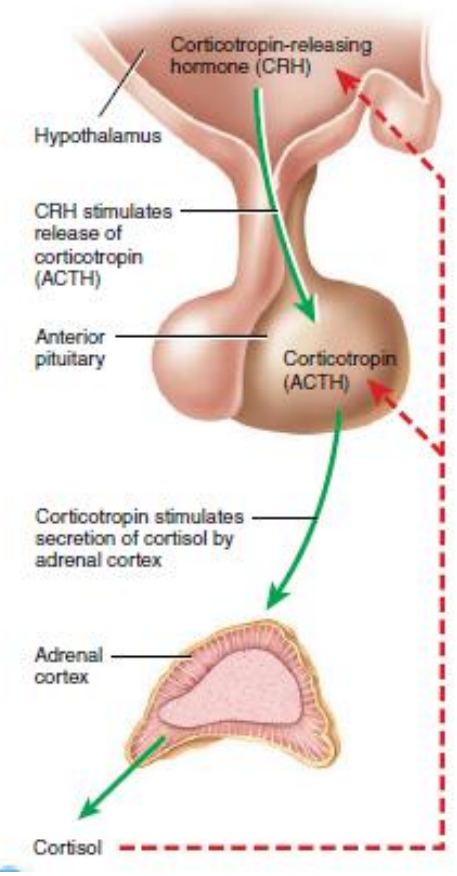

Sekresi hormon hipofisis anterior diatur dalam dua cara. Pertama, sel neurosecretory di hipotalamus mensekresi lima hormon dan merelease, yang menstimulasi sekresi hormon hipofisis anterior, dan dua hormon penghambat, yang menekan sekresi hormon hipofisis anterior. Kedua, umpan balik negatif berbentuk hormon yang dikeluarkan oleh kelenjar Target menurunkan sekresi untuk tiga jenis sel hipofisis anterior. Dalam umpan balik negatif seperti loop, aktivitas sekresi dari thyrotrophs, gonadotrophs, dan corticotrophs menurun bila kadar hormon kelenjar target mereka meningkat.

adrenocorticotropic Misalnya, (ACTH) menstimulasi kelenjar korteks adrenal untuk mensekresi

glukokortikoid, terutama kortisol. Selanjutnya, tingkat darah yang meningkat kortisol menurunkan sekresi baik corticotropin dan corticotropin-releasing hormone $(\mathrm{CRH})$ dengan cara menekan aktivitas corticotrophs hipofisis anterior dan sel neurosecretory hipotalamus.

\begin{tabular}{|c|c|c|c|}
\hline \multicolumn{4}{|c|}{ Hormones of the Anterior Pituitary } \\
\hline HORMONE & SECRETED BY & $\begin{array}{l}\text { HYPOTHALAMIC RELEASING } \\
\text { HORMONE (STIMULATES SECRETION) }\end{array}$ & $\begin{array}{l}\text { HYPOTHALAMIC INHIBITING } \\
\text { HORMONE (SUPPRESSES SECRETION) }\end{array}$ \\
\hline $\begin{array}{l}\text { Human growth hormone (hGH), } \\
\text { also known as somatotropin }\end{array}$ & Somatotrophs. & $\begin{array}{l}\text { Growth hormone-releasing hormone (GHRH), } \\
\text { also known as somatocrinin. }\end{array}$ & $\begin{array}{l}\text { Growth hormone-inhibiting hormone }(\mathrm{GHIH}) \text {, } \\
\text { also known as somatostatin. }\end{array}$ \\
\hline $\begin{array}{l}\text { Thyroid-stimulating hormone } \\
\text { (TSH), also known as thyrotropin }\end{array}$ & Thyrotrophs. & Thyrotropin-releasing hormone (TRH). & Growth hormone-inhibiting hormone (GHIH). \\
\hline Follicle-stimulating hormone (FSH) & Gonadotrophs. & Gonadotropin-releasing hormone (GnRH). & - \\
\hline Luteinizing hormone (LH) & Gonadotrophs. & Gonadotropin-releasing hormone ( $\mathrm{GnRH})$. & - \\
\hline Prolactin (PRL) & Lactotrophs. & Prolactin-releasing hormone (PRH).* & $\begin{array}{l}\text { Prolactin-inhibiting hormone (PIH), which is } \\
\text { dopamine. }\end{array}$ \\
\hline $\begin{array}{l}\text { Adrenocorticotropic hormone } \\
\text { (ACTH), also known as } \\
\text { corticotropin }\end{array}$ & Corticotrophs. & Corticotropin-releasing hormone (CRH). & - \\
\hline $\begin{array}{l}\text { Melanocyte-stimulating } \\
\text { hormone (MSH) }\end{array}$ & Corticotrophs. & Corticotropin-releasing hormone (CRH). & Dopamine. \\
\hline
\end{tabular}

\section{Human Growth Hormone and Insulinlike Growth Factors}

Somatotrophs adalah sel sebagian besar banyak di hipofisis anterior, dan human growth hormone (hGH) merupakan hormon yang paling berlimpah dihipofisis 
anterior. Fungsi utama dari hGH adalah untuk meningkatkan sintesis dan sekresi hormon protein kecil yang disebut insulinlike growth factor atau somatomedins. sebagai respon human growth hormon, sel-sel di hati, otot rangka, kartilago, tulang, dan jaringan lainnya mensekresikan IGFs, dimana mungkin juga masuk ke aliran darah dari hati atau berperan secara lokal di jaringan lain sebagai autocrines atau paracrines.

Fungsi IGFs antara lain sebagai berikut:

1) IGFs menyebabkan sel untuk tumbuh dan berkembang biak dengan cara meningkatkan uptake asam amino ke dalam sel dan mempercepat sintesis protein. IGFs juga memperkecil pemecahan protein dan pemanfaatan asam amino untuk produksi ATP. Karena efek dari IGFs, human growth hormone meningkatkan tingkat pertumbuhan kerangka dan otot rangka selama masa kanak-kanak dan remaja. Pada orang dewasa, human growth hormone dan IGFs membantu mempertahankan massa otot dan tulang dan meningkatkan penyembuhan luka dan perbaikan jaringan.

2) IGFs juga meningkatkan lipolisis di jaringan adiposa, yang menghasilkan peningkatan penggunaan fatty acids dalam merilis untuk memproduksi ATP oleh sel-sel tubuh.

3) Selain mempengaruhi protein dan lipid metabolisme, growth hormone manusia dan IGFs mempengaruhi metabolisme karbohidrat dengan cara menurunkan uptake glukosa, dimana mengurangi penggunaan glukosa untuk memproduksi ATP oleh sel-sel tubuh sebagian besar. Tindakan ini akan menyimpan glukosa sehingga tersedia untuk neuron produksi ATP di saat kekurangan glukosa. IGFs dan human growth hormone juga menstimulasi sel-sel hati untuk melepaskan glukosa ke dalam darah.

Figure 18.7 Effects of human growth hormone (hGH) and insulinlike growth factors (IGFs). Solid green arrows indicate stimulation of secretion; dashed red arrows indicate inhibition of secretion via negative feedback.

Secretion of hGH is stimulated by growth hormone releasing hormone (GHRH) and inhibited by growth hormone-Inhibiting hormone (GHIH).

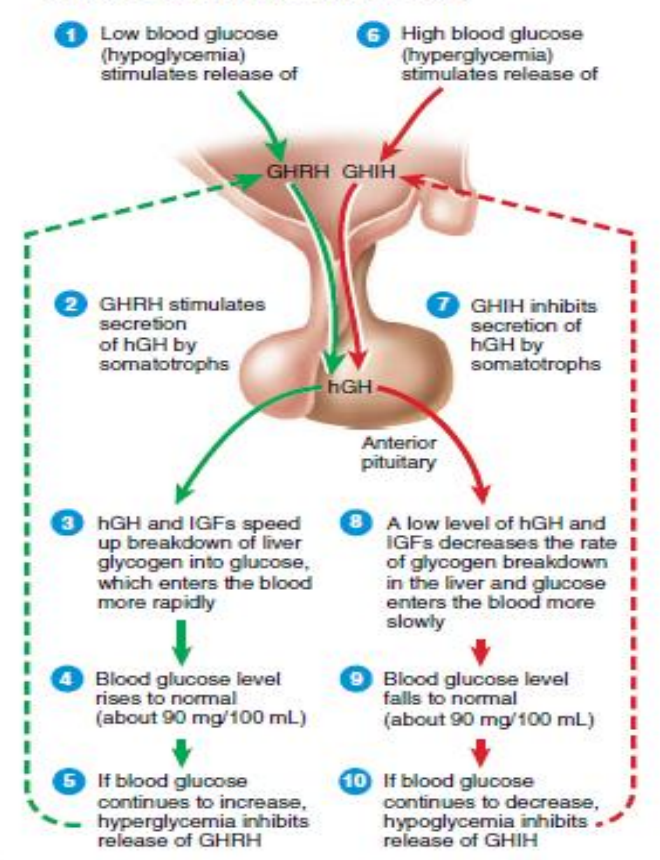

Somatotrophs di hipofisis anterior merelease human growth hormone setiap beberapa jam, khususnya saat tidur. Kegiatan ini dikontrol terutama oleh dua hormon hipotalamus: (1) growth hormone-releasing hormone (GHRH) meningkatkan sekresi human growth hormone, dan (2) growth hormone-inhibiting hormone (GHIH) dapat menekan produksi hormon. Regulator utama dari sekresi GHRH dan GHIH merupakan tingkat glukosa darah. 
1) Hipoglikemia suatu konsentrasi glukosa darah yang rendah secara abnormal, menstimulasi hipotalamus untuk mensekresikan GHRH, yang mengalir menuju hipofisis anterior di vena Portal hypophyseal

2) Pada mencapai hipofisis anterior, GHRH menstimulasi somatotrophs untuk melepaskan human growth hormone.

3) Human growth hormone menstimulasi sekresi growth factors insulinlike, yang mempercepat pemecahan glycogen di hati menjadi glukosa, menyebabkan glukosa untuk masuk kedalam darah lebih cepat.

4) Hasilnya, glukosa darah yang naik ke tingkat normal (sekitar $90 \mathrm{mg} / 100 \mathrm{~mL}$ plasma darah yang).

5) Peningkatan dalam glukosa darah di atas batas normal menghambat pelepasan GHRH.

6) Hiperglikemia, suatu konsentrasi glukosa darah yang normal tinggi, menstimulasi hipotalamus untuk mensekresikan GHIH (sementara menghambat sekresi GHRH).

7) Ketika sampai di hipofisis anterior di dalam darah portal, GHIH menghambat sekresi growth hormone manusia dengan somatotrophs.

8) Sebuah rendahnya human growth hormone dan IGFs memperlambat pemecahan glikogen dalam hati, dan glukosa dirilis ke dalam darah lebih lambat.

9) Glukosa darah turun ke tingkat normal.

10) Penurunan glukosa darah yang di bawah tingkat normal (hipoglikemia) menghambat pelepasan GHIH.

Rangsangan lain yang meningkatkan sekresi human growth hormone termasuk penurunan fatty acids dan peningkatan asam amino dalam darah; tidur yang mendalam (tahap 3 dan 4 non-rapid eye movement sleep); peningkatan aktivitas dari divisi simpatik dari sistem saraf otonom, seperti yang mungkin terjadi pada stres atau latihan fisik yang kuat; dan hormon lainnya, termasuk glukagon, estrogen, kortisol, dan insulin. Faktor-faktor yang menghambat sekresi human growth hormone peningkatan kadar fatty acids dan penurunan kadar asam amino dalam darah; rapit sleep eye movement; kekurangan emosional; obesitas; rendahnya tingkat hormon tiroid; dan human growth hormone itu sendiri (melalui umpan balik negatif). Growth hormon inhibisi hormon (GHIH), alternatif dikenal sebagai somatostatin, juga menghambat sekresi human growth hormone.

\section{Thyroid-Stimulating Hormone}

Thyroid-stimulating hormone (TSH) menstimulasi sintesis dan sekresi dua hormon tiroid, triiodothyronine (T3) dan thyroxine (T4), keduanya diproduksi oleh kelenjar tiroid. Thyrotropin-releasing hormone (TRH) dari hipotalamus mengontrol sekresi TSH. Pelepasan TRH kemudian bergantung pada kadar T3 
dan T4; tingginya tingkat T3 dan T4 menghambat sekresi TRH melalui umpan balik negatif.

\section{Follicle-Stimulating Hormone}

Pada wanita, ovarium merupakan target untuk follicle-stimulating hormone (FSH). Setiap bulan FSH memulai pengembangan beberapa folikel ovarium, pengaturan saclike sel sekretori yang mengelilingi oosit berkembang. FSH juga menstimulasi sel-sel folikel untuk mensekresikan estrogen (hormon seks wanita). Pada laki-laki, FSH menstimulasi produksi sperma di testis. Gonadotropinreleasing hormone $(\mathrm{GnRH})$ dari hipotalamus menstimulasi pelepasan FSH. Pelepasan GnRH dan FSH ditekan oleh estrogen pada wanita dan testosteron oleh (prinsip hormon seks pria) pada laki-laki melalui sistem umpan balik negatif. Tidak ada gonadotropin inhibisi hormone.

\section{luteinizing Hormone}

Pada wanita, hormone luteinizing (LH) memicu ovulasi, pelepasan oosit sekunder (ovum di masa depan) oleh ovarium. LH menstimulasi pembentukan korpus luteum (struktur terbentuk setelah ovulasi) di ovarium dan sekresi progesteron (hormon seks wanita lain) oleh korpus luteum. Bersama-sama, FSH dan LH juga menstimulasi sekresi estrogen oleh sel ovarium. Estrogen dan progesteron mempersiapkan rahim untuk implantasi dari ovum yang dibuahi dan membantu mempersiapkan kelenjar susu untuk sekresi susu. Pada laki-laki, LH menstimulasi sel-sel dalam testis untuk mensekresikan testosteron. Sekresi LH, seperti itu dari FSH, dikendalikan oleh hormone gonadotropin-releasing hormone (GnRH).

\section{Prolaktin}

Prolaktin (PRL), bersama-sama pada hormon lain, inisiasi dan mempertahankan produksi ASI oleh kelenjar payudara. Dengan sendirinya, prolaktin hanya memiliki efek yang lemah. Hanya setelah kelenjar payudara telah prima oleh estrogen, progesteron, glukokortikoid, human growth hormone, tiroksin, dan insulin, dimana memberi efek permisif, apakah PRL menghasilkan produksi ASI. Ejeksi susu dari kelenjar payudara tergantung pada hormon oksitosin, dimana dirilis dari hipofisis posterior. Bersama-sama, produksi ASI dan ejeksi merupakan laktasi.

Hipotalamus mengeluarkan kedua hormon inhibitor dan rangsang yang mengatur sekresi prolaktin. Pada wanita, hormone prolactininhibiting (PIH), yang merupakan dopamin, menghambat pelepasan prolaktin dari hipofisis anterior sering kali. Setiap bulan, sebelum menstruasi dimulai, sekresi PIH berkurang dan tingkat darah prolaktin meningkat, namun belum cukup untuk menstimulasi produksi ASI. Nyeri payudara sebelum menstruasi dapat disebabkan oleh prolaktin tinggi. Sebagaimana dalam siklus menstruasi berulang kembali, PIH ini kembali 
disekresi dan tingkat prolaktin menurun. Selama kehamilan, tingkat prolaktin naik, distimulasi oleh prolaktin-releasing hormone (PRH) oleh hipotalamus. Mengisap tindakan seorang bayi menyusui menyebabkan penurunan sekresi PIH dari hipotalamus.

Fungsi prolaktin ini tidak diketahui pada laki-laki, namun hipersekresi yang menyebabkan disfungsi ereksi (impotensi, ketidakmampuan untuk memiliki ereksi penis). Pada wanita, hipersekresi prolaktin menyebabkan galaktorea (laktasi tidak pantas) dan amenore (tidak adanya siklus menstruasi)

\section{Hormon adrenokortikotropik}

Corticotrophs mensekresikan hormone utamanya adrenokortikotropik (ACTH). ACTH mengontrol produksi dan sekresi kortisol dan glukokortikoid lainnya oleh korteks (bagian terluar) dari kelenjar adrenal. Corticotropin-releasing hormone (CRH) oleh hipotalamus menstimulasi sekresi ACTH oleh corticotrophs. Rangsangan stres yang berhubungan, seperti misalnya glukosa darah rendah atau trauma fisik, dan interleukin-1, zat yang diproduksi oleh makrofag, juga menstimulasi pelepasan ACTH. Glukokortikoid menghambat CRH dan ACTH release melalui umpan balik negatif.

\section{Melanosit-Stimulating Hormone}

Melanosit-stimulating hormone (MSH) meningkatkan pigmentasi kulit amfibi dengan merangsang penyebaran butiran melanin di melanosit. Peran yang tepat dalam manusia tidak diketahui, namun keberadaan reseptor MSH dalam otak mempengaruhi aktivitas otak. Ada sedikit beredar MSH pada manusia. Namun, pemberian terus MSH selama beberapa hari tidak menghasilkan suatu kulit gelap. Tingkat berlebihan corticotropin-releasing hormone (CRH) dapat menstimulasi release $\mathrm{MSH}$; dopamin menghambat pelepasan $\mathrm{MSH}$.

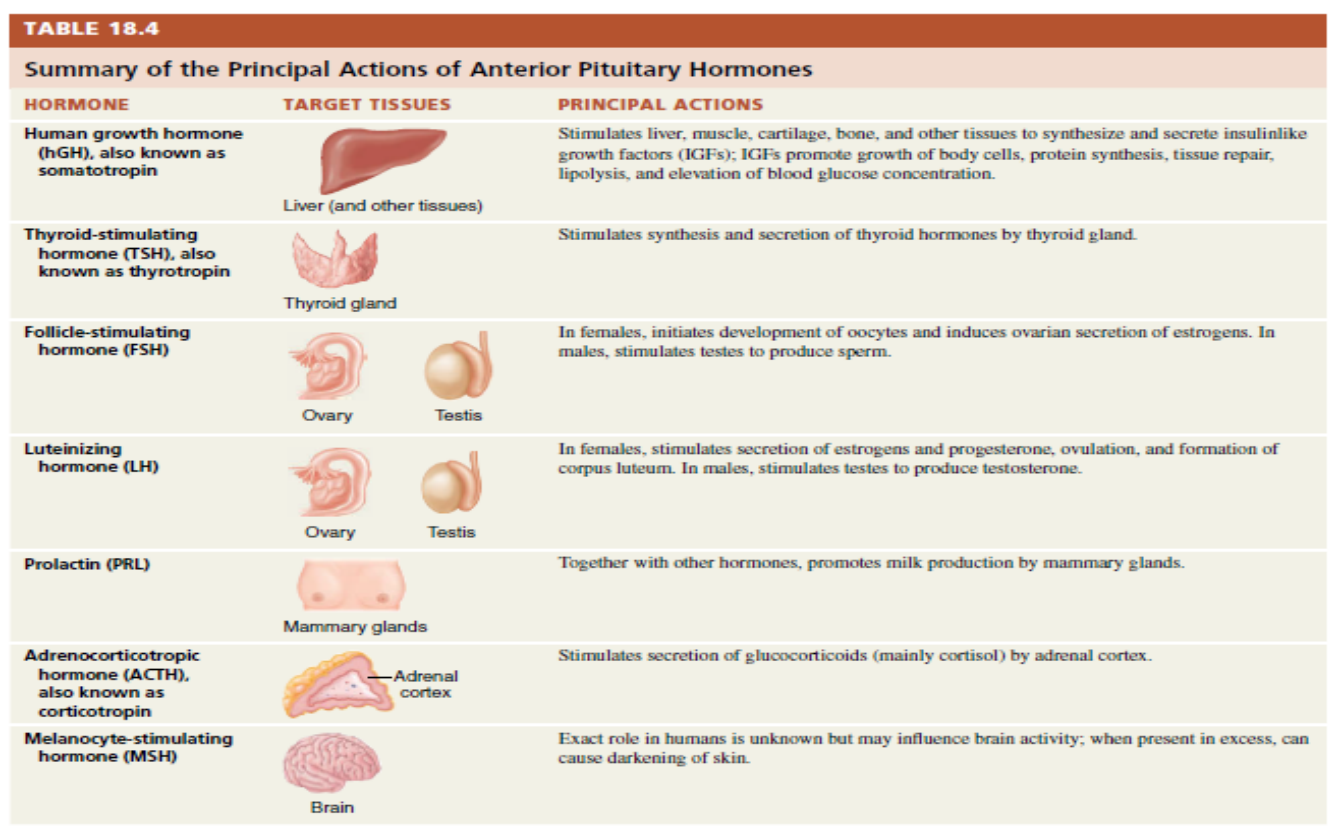




\section{b. Hipofisis Posterior}

Walaupun hipofisis posterior atau neurohypophysis tidak mensintesa hormon, hal itu menyimpan dan melepaskan dua hormon. Ini terdiri atas akson dan terminal akson lebih dari 10.000 sel neurosecretory hipotalamus. sel sel neurosecretory berada di paraventrikular dan supraoptik inti hipotalamus; akson mereka membentuk saluran hypothalamohypophyseal.

Saluran ini dimulai di hipotalamus dan berakhir di dekat kapiler darah di hipofisis posterior. Para badan sel saraf baik dari paraventrikular dan inti supraoptik mensintesa hormon oksitosin dan hormone antidiuretik (ADH), disebut juga vasopressin. Terminal akson di hipofisis posterior berhubungan dengan neuroglia khusus yang disebut pituicytes. Sel-sel ini memiliki peran pendukung mirip dengan astrosit.

Setelah produksi mereka di badan sel sel neurosecretory, oksitosin dan hormon antidiuretik dikemas ke dalam vesikel sekretorik, dimana bergerak dengan transportasi aksonal cepat ke terminal akson di hipofisis posterior, keberadaan mereka disimpan sampai impuls saraf memicu eksositosis dan pelepasan hormon.

Darah disuplai ke hipofisis posterior oleh arteri hypophyseal inferior, arteri ini cabang dari arteri karotis interna. Dalam hipofisis posterior, arteri hypophyseal inferior mengalir menuju pleksus kapiler dalam proses infundibular, jaringan kapiler yang mendapat sekresi oksitosin dan hormon antidiuretik. Dari pleksus ini, hormon masuk ke pembuluh darah hypophyseal posterior untuk distribusi menuju sel-sel dalam jaringan target.

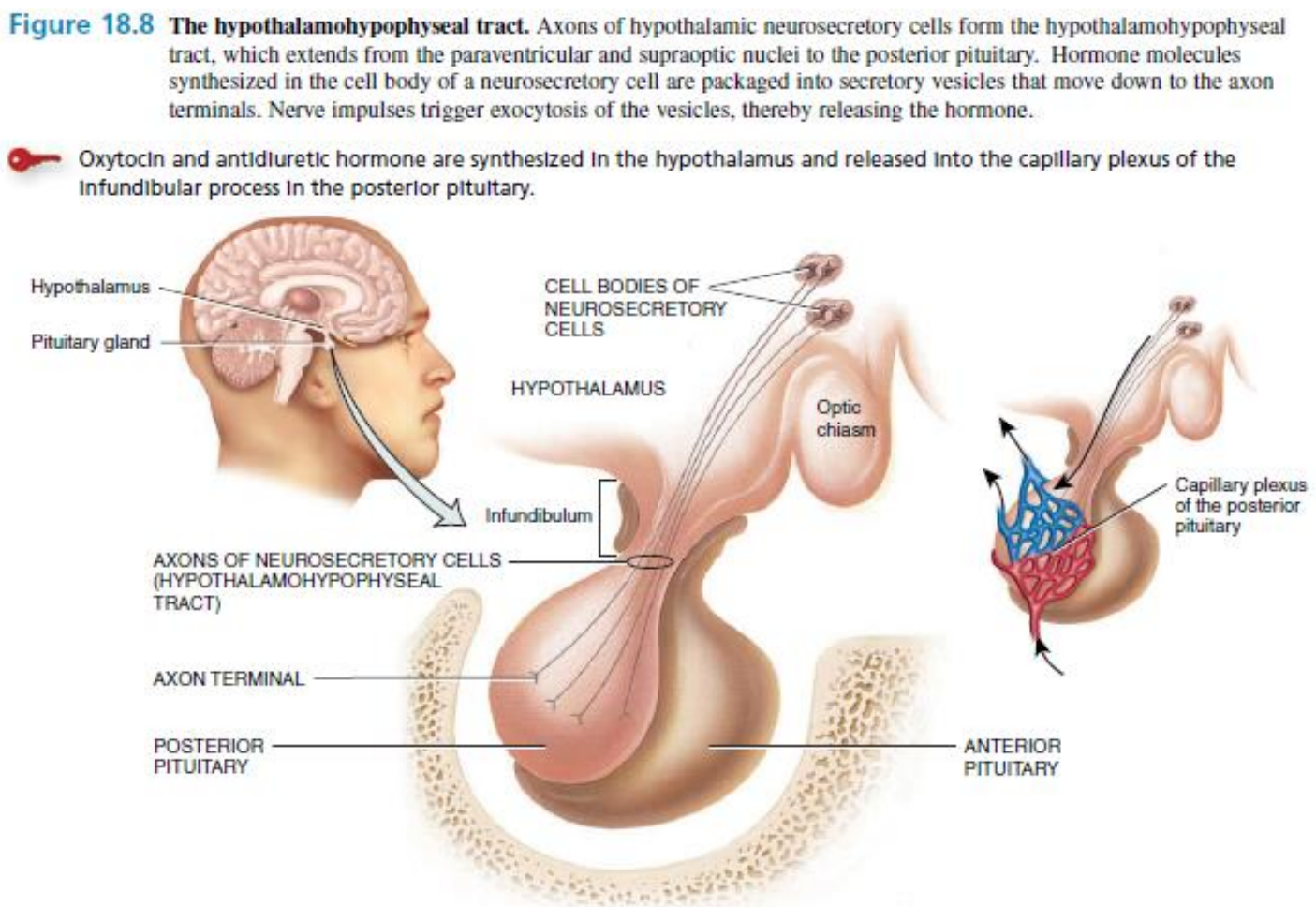

\section{Pengendalian Sekresi oleh posterior hipofisis}

Oksitosin Pada saat dan setelah persalinan seorang bayi, oksitosin mempengaruhi dua jaringan target: rahim ibu dan payudara. Saat persalinan, peregangan leher rahim 
rahim merangsang pelepasan oksitosin dimana, pada gilirannya akan, dapat meningkatkan kontraksi sel otot polos pada dinding rahim; setelah persalinan, merangsang susu ejeksi ("letdown") dari kelenjar payudara sebagai respons terhadap stimulus mekanik diberikan oleh bayi suckling. Fungsi oksitosin pada laki-laki dan pada wanita tidak hamil belum jelas. Percobaan pada hewan telah menyarankan bahwa ia memiliki tindakan dalam dalam otak yang mendorong perilaku perawatan orangtua terhadap anaknya anak. Ini mungkin juga bertanggung jawab, sebagian, untuk perasaan kenikmatan seksual saat dan setelah hubungan seksual.

\section{Antidiuretik Hormon}

Sesuai dengan namanya, sebuah hormon antidiuretik adalah zat yang menurunkan produksi urine. ADH menyebabkan ginjal untuk mengembalikan lebih banyak air ke dalam darah, sehingga menurunkan volume urine. Dengan tidak adanya ADH, urin meningkat lebih dari sepuluh kali lipat, dari yang normal 1 sampai 2 liter menjadi sekitar 20 liter per hari. Minum alkohol sering menyebabkan sering buang air kecil dan berlebihan karena alkohol menghambat sekresi ADH. ADH juga menyebabkan berkurangnya hilangnya air melalui keringat dan menyebabkan penyempitan arteriol, yang meningkatkan tekanan darah. hormone ini ini lain nama, vasopressin, menggambarkan efek terhadap tekanan darah.

Banyaknya ADH disekresi bervariasi tergantung tekanan osmotik darah dan volume darah, berikut penjelasannya:

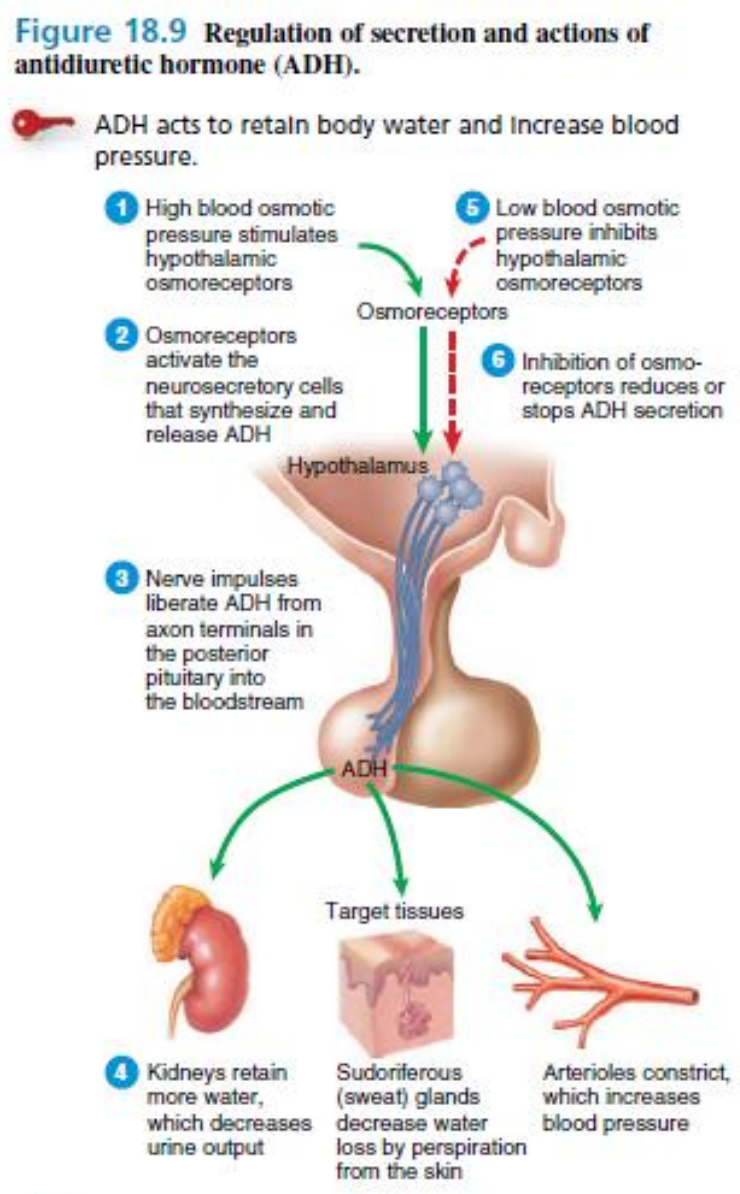


(1) Tekanan osmotik darah tinggi (atau penurunan volume darah) -karena dehidrasi atau penurunan volume darah karena perdarahan, diare, atau berlebihan berkeringat-menstimulasi osmoreseptor, neuron di hipotalamus yang memonitor tekanan osmotik darah yang. Tekanan osmotik darah mengaktifkan osmoreseptor secara langsung; mereka juga menerima input rangsang dari daerah otak lainnya bila volume darah menurun.

(2) Osmoreseptor mengaktifkan sel-sel neurosecretory hipotalamus yang mensintesis dan melepaskan ADH

(3) Bila sel-sel neurosecretory menerima input rangsang dari osmoreseptor, mereka menghasilkan impuls saraf yang menimbulkan eksositosis ADH yang mengandung vesikel dari terminal akson mereka di hipofisis posterior. Hal ini melepaskan $\mathrm{ADH}$, dimana berdifusi ke kapiler darah hipofisis posterior.

(4) Darah membawa ADH tiga jaringan target: ginjal, sudoriferous (keringat) kelenjar, dan otot polos di dinding pembuluh darah. Ginjal merespon dengan mempertahankan lebih banyak air, yang akan menurunkan produksi urine. Kegiatan Sekretori kelenjar keringat menurun, yang menurunkan tingkat kehilangan air dengan keringat dari kulit. Otot polos di dinding arteriol (arteri kecil) kontrak sebagai respons terhadap tingginya tingkat $\mathrm{ADH}$, dimana konstriksi (menyempit) lumen pembuluh darah tersebut dan meningkatkan tekanan darah.

(5) Tekanan osmotik darah rendah (atau volume darah meningkat) dapat menghambat osmoreseptor.

(6) Inhibisi osmoreseptor menurunkan atau menghentikan sekresi ADH. Ginjal kemudian menahan air kurang dengan cara membentuk lebih besar volume dari urin, aktivitas sekresi kelenjar keringat meningkat, dan arteriol melebar. Volume darah dan tekanan osmotik cairan tubuh kembali normal

Sekresi ADH juga dapat diubah dengan cara lain. Nyeri, stres, trauma, kecemasan, asetilkolin, nikotin, dan obat-obatan seperti morfin, obat penenang, dan beberapa anestesi menstimulasi sekresi ADH. Efek dehidrasi alkohol, dimana telah disebutkan, dapat menyebabkan baik haus dan sakit kepala khas mabuk. Hyposecretion ADH atau reseptor ADH nonfungsional menyebabkan diabetes insipidius.

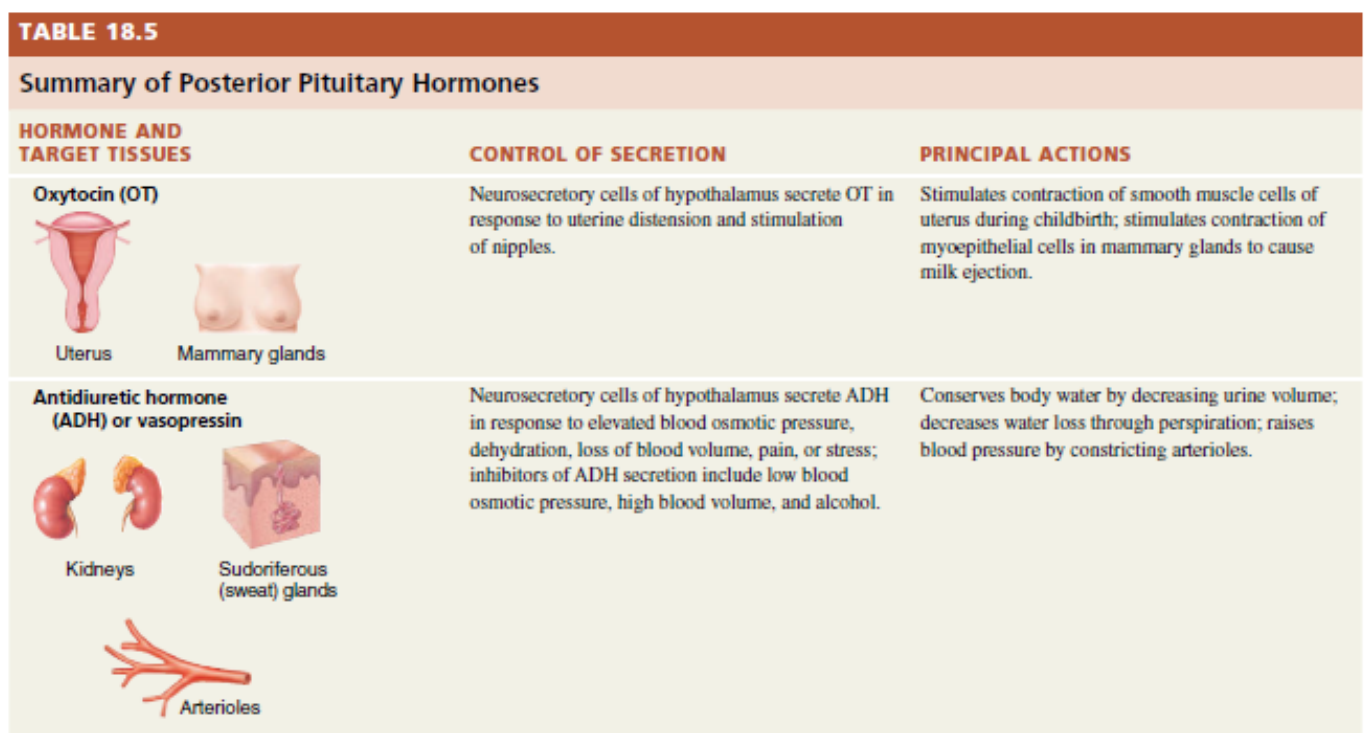




\section{Kelenjar thyroid}

Kelenjar tiroid berbentuk kupu-kupu berada di inferior laring (kotak suara). Terdiri dari lobus lateral kanan dan kiri, terletak di kedua sisi trakea, yang dihubungkan oleh sebuah isthimus anterior ke trakea (Gambar 18.10a). Sekitar 50\% dari kelenjar tiroid memiliki tiga lobus kecil, yang disebut lobus piramidal. Memanjang superior dari isthmus. Massa normal tiroid adalah sekitar $30 \mathrm{~g}(1 \mathrm{oz})$.

Kantung berbentuk bola mikroskopis disebut folikel tiroid membentuk kebanyakan kelenjar tiroid. Dinding setiap folikel utamanya terdiri dari sel yang disebut sel folikel, yang sebagian besar memperluas ke lumen (ruang internal) dari folikel. Sebuah membran basal mengelilingi setiap folikel. Bila sel-sel folikel yang tidak aktif, berbentuk cuboidal Rendah hingga skuamosa, tetapi di bawah pengaruh TSH mereka menjadi aktif dalam sekresi dan dalam bentuk yang mulai dari cuboidal ke kolumnar rendah. Sel-sel folikel menghasilkan dua hormon: tiroksin, yang juga disebut tetraiodothyronine (T4) karena mengandung empat atom yodium, dan triiodothyronine (T3), yang berisi tiga atom yodium. T3 dan T4 bersama-sama juga dikenal sebagai hormon tiroid. Beberapa sel yang disebut sel parafollicular atau sel C terletak di antara folikel. Mereka menghasilkan hormon kalsitonin (CT), yang membantu mengatur homeostasis kalsium.

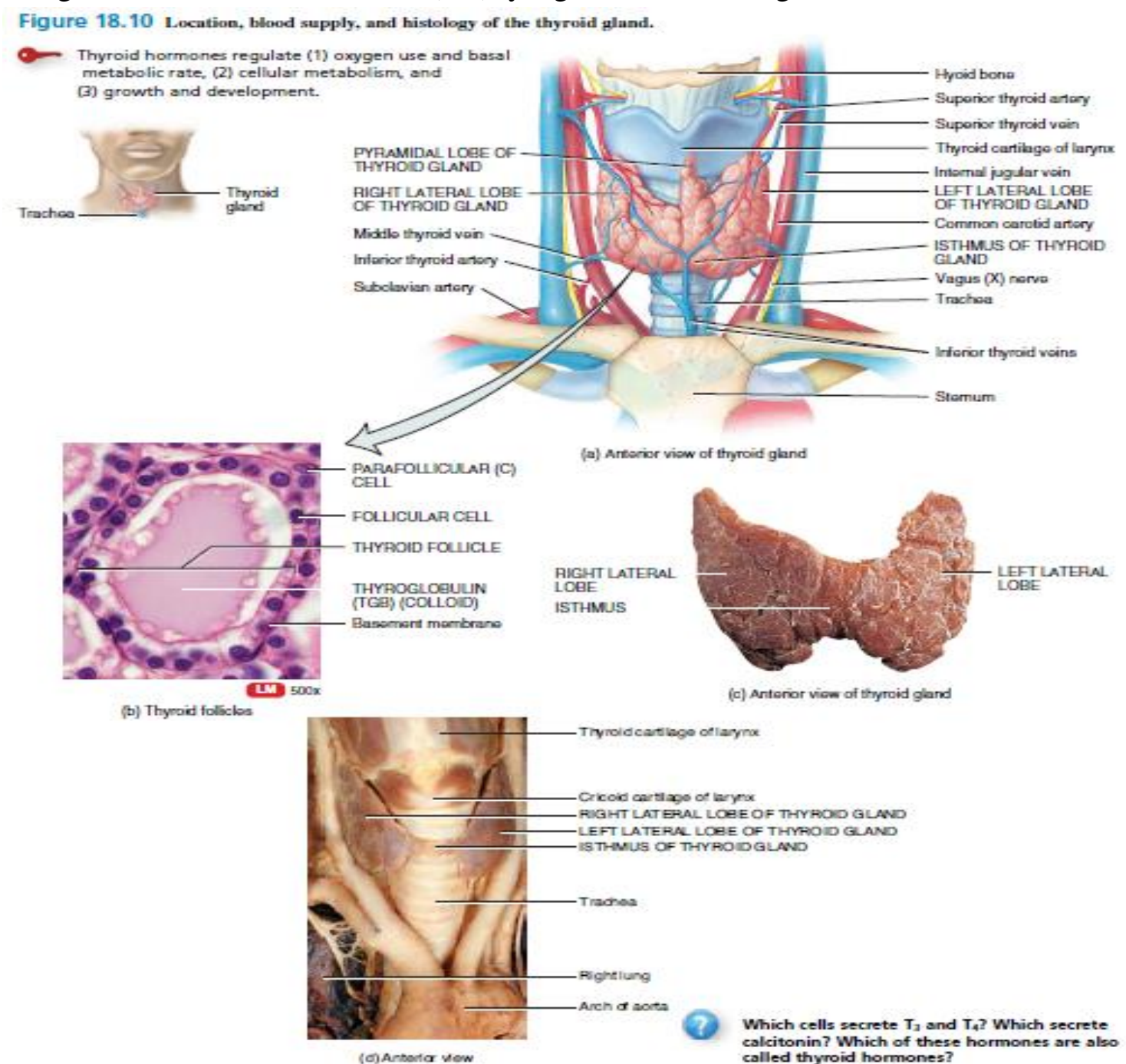




\section{Susunan, Penyimpanan, dan Pelepasan Tiroid Hormon}

Kelenjar tiroid adalah satu-satunya kelenjar endokrin yang menyimpan produk sekretori dalam besar jumlah-biasanya sekitar persediaan 100-hari. Sintesis dan sekresi T3 dan T4 terjadi sebagai berikut:

1. Trapping iodida. Tiroid folikel sel trap iodida ion dengan aktif mengangkutnya dari darah ke sitosol. Hasilnya, kelenjar tiroid secara normal mengandung sebagian besar iodida dalam tubuh.

2. Sintesis tiroglobulin. Meskipun sel-sel folikel yang Trapping, mereka juga sintesis tiroglobulin (TGB), suatu glikoprotein besar yang dihasilkan dalam retikulum endoplasma, yang dimodifikasi di kompleks Golgi, dan dikemas dalam vesikel sekretorik. Vesikel kemudian menjalani eksositosis, yang melepaskan TGB ke dalam lumen folikel.

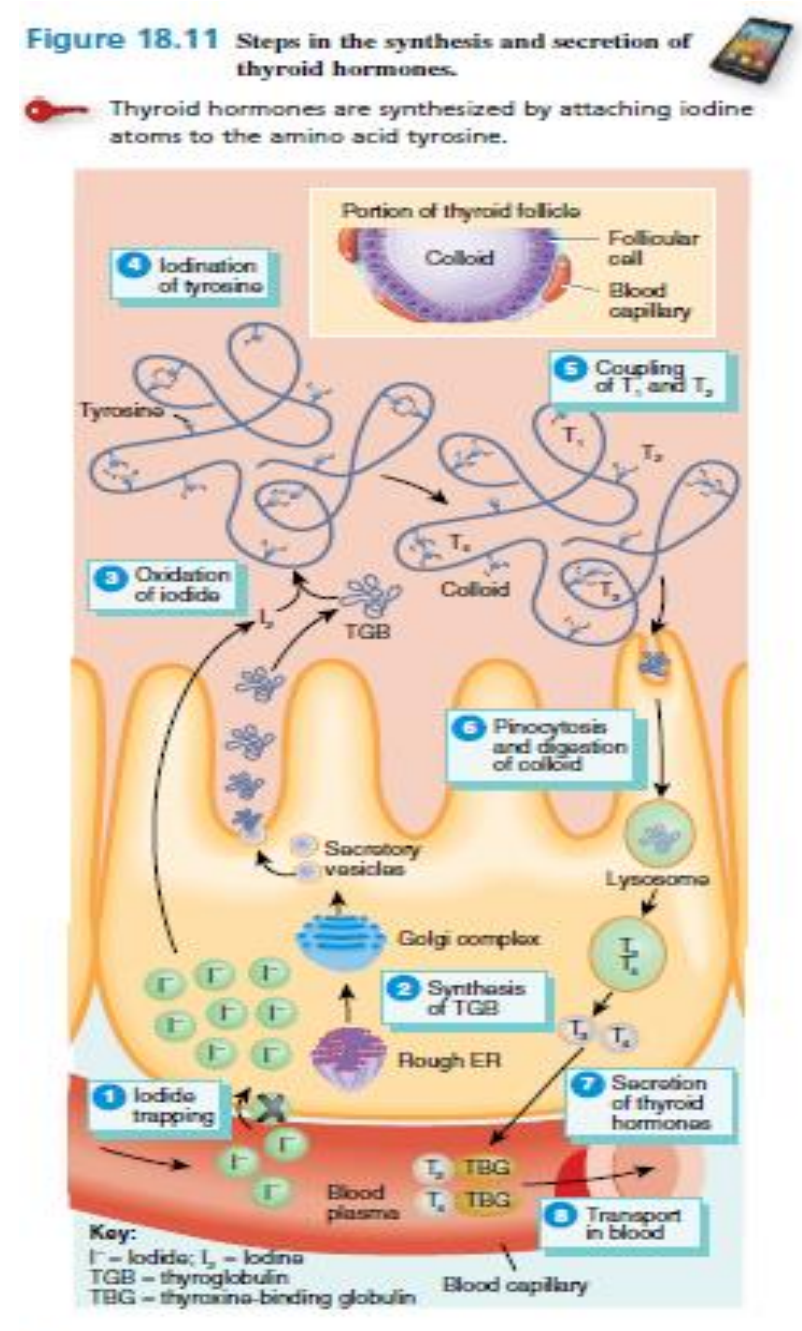

(3)Oksidasi iodida. Beberapa asam amino di TGB adalah tyrosines yang akan menjadi iodinasi. Namun, ion iodida bermuatan negatif tidak dapat mengikat tirosin sampai mereka mengalami oksidasi (pengangkatan elektron) ke yodium: Sebagaimana ion iodida sedang teroksidasi, mereka melewati membran ke dalam lumen folikel.

(4) Iodinasi tirosin. Sebagaimana molekul yodium (I2) bentuk, mereka bereaksi dengan tyrosines yang merupakan bagian dari molekul tiroglobulin. Pengikatan satu hasil yodium atom monoiodotyrosine (T1), dan iodinasi kedua menghasilkan Diiodothyrosine (T2). TGB dengan atom yodium menempel, bahan lengket yang terakumulasi dan disimpan dalam lumen folikel tiroid, yang disebut koloid.

(5) Coupling T1 dan T2. Pada saat tahap terakhir dalam sintesis hormon

tiroid, dua molekul T2 bergabung untuk membentuk T4, atau satu T1 dan T2 satu bergabung untuk membentuk T3.

(6) Pinositosis dan pencernaan koloid. Butiran koloid masuk kembali ke sel-sel folikel dengan pinositosis dan bergabung dengan lisosom. Enzim pencernaan dalam lisosom memecah TGB, membelah dari molekul T3 dan T4.

(7) Sekresi hormon tiroid. Karena T3 dan T4 yang larut lemak, mereka menyebar melalui membran plasma ke dalam cairan interstitial dan kemudian ke dalam darah. 
T4 biasanya disekresikan dalam jumlah yang lebih besar dari T3, tetapi T3 adalah beberapa kali lebih kuat. Selain itu, setelah T4 memasuki sel tubuh, sebagian besar diubah menjadi T3 oleh penghapusan satu yodium.

(8) Transportasi dalam darah. Lebih dari 99\% baik dari T3 dan T4 menggabungkan dengan protein transport dalam darah, utamanya thyroxine-binding globulin (TBG).

\section{Aksi Tiroid Hormon}

Karena tubuh sel-sel memiliki reseptor untuk hormon tiroid, T3 dan T4 menggunakan efeknya ke seluruh tubuh.

1) Hormon tiroid meningkatkan metabolisme basal rate (BMR), laju pemakaian oksigen dalam kondisi standar atau basal (terjaga, saat istirahat, dan puasa), dengan merangsang penggunaan oksigen seluler untuk menghasilkan ATP. Ketika meningkat basal metabolic rate, metabolisme sel karbohidrat, lipid, dan protein meningkat.

2) Efek utama kedua hormon tiroid adalah untuk menstimulasi sintesis tambahan pompa natrium-kalium. dimana menggunakan jumlah besar ATP untuk senantiasa mengeluarkan ion natrium dari sitosol ke dalam ion cairan dan kalium ekstraseluler dari cairan ekstraseluler ke dalam sitosol. Seperti sel-sel produksi dan lebih banyak menggunakan ATP, banyak panas yang dilepaskan, dan suhu tubuh meningkat. Fenomena ini disebut efek calorigenic. Dengan cara ini, hormon tiroid memainkan peran penting dalam pemeliharaan suhu tubuh normal. Mamalia yang normal dapat bertahan hidup dalam suhu beku, namun mereka yang memiliki tiroid kelenjar telah dilepaskan tidak bisa.

3) Dalam regulasi metabolisme, hormon tiroid menstimulasi sintesis protein dan meningkatkan penggunaan glukosa dan asam lemak untuk produksi ATP. Mereka juga meningkatkan lipolisis dan meningkatkan ekskresi kolesterol, sehingga mengurangi kadar kolesterol darah.

4) Hormon tiroid meningkatkan beberapa tindakan katekolamin (norepinefrin dan epinefrin) karena mereka upregulate reseptor beta. Untuk alasan ini, gejala hipertiroid meliputi peningkatan heart rate, denyut jantung lebih kuat, dan peningkatan tekanan darah.

5) Sama dengan growth hormone manusia dan insulin, hormon tiroid percepatan pertumbuhan tubuh, terutama pertumbuhan sistem saraf dan tulang. Kekurangan hormon tiroid selama perkembangan janin, bayi, atau anak usia menyebabkan keterbelakangan mental yang berat dan pertumbuhan tulang terhambat.

\section{Kontrol Sekresi Tiroid Hormon}

Thyrotropin-releasing hormone (TRH) dari hipotalamus dan thyroid-stimulating hormone (TSH) dari hipofisis anterior menstimulasi sintesis dan pelepasan hormon tiroid. Seperti keterangan dibawah:

1) Tingkat darah rendah $\mathrm{T} 3$ dan $\mathrm{T} 4$ atau tingkat metabolisme yang rendah menstimulasi hipotalamus untuk mensekresikan TRH. 
2) TRH memasuki vena Portal hypophyseal dan mengalir ke hipofisis anterior, keberadaan merangsang thyrotrophs untuk mensekresikan TSH.

3) TSH menstimulasi hampir semua aspek aktivitas sel folikel tiroid, termasuk iodida Trapping (1 Gambar), sintesis hormone dan sekresi (2 dan 7 pada Gambar), dan pertumbuhan sel-sel folikel.

4) Sel-sel folikel tiroid release $\mathrm{T} 3$ dan $\mathrm{T} 4$ ke dalam darah sampai kembali tingkat metabolisme normal.

5) Tingkat yang lebih tinggi dari T3 menghambat pelepasan TRH dan TSH (inhibisi umpan balik negatif).

Kondisi yang meningkatkan ATP permintaan lingkungan yang dingin, hipoglikemia, ketinggian, dan kehamilan-juga meningkatkan sekresi hormon tiroid.

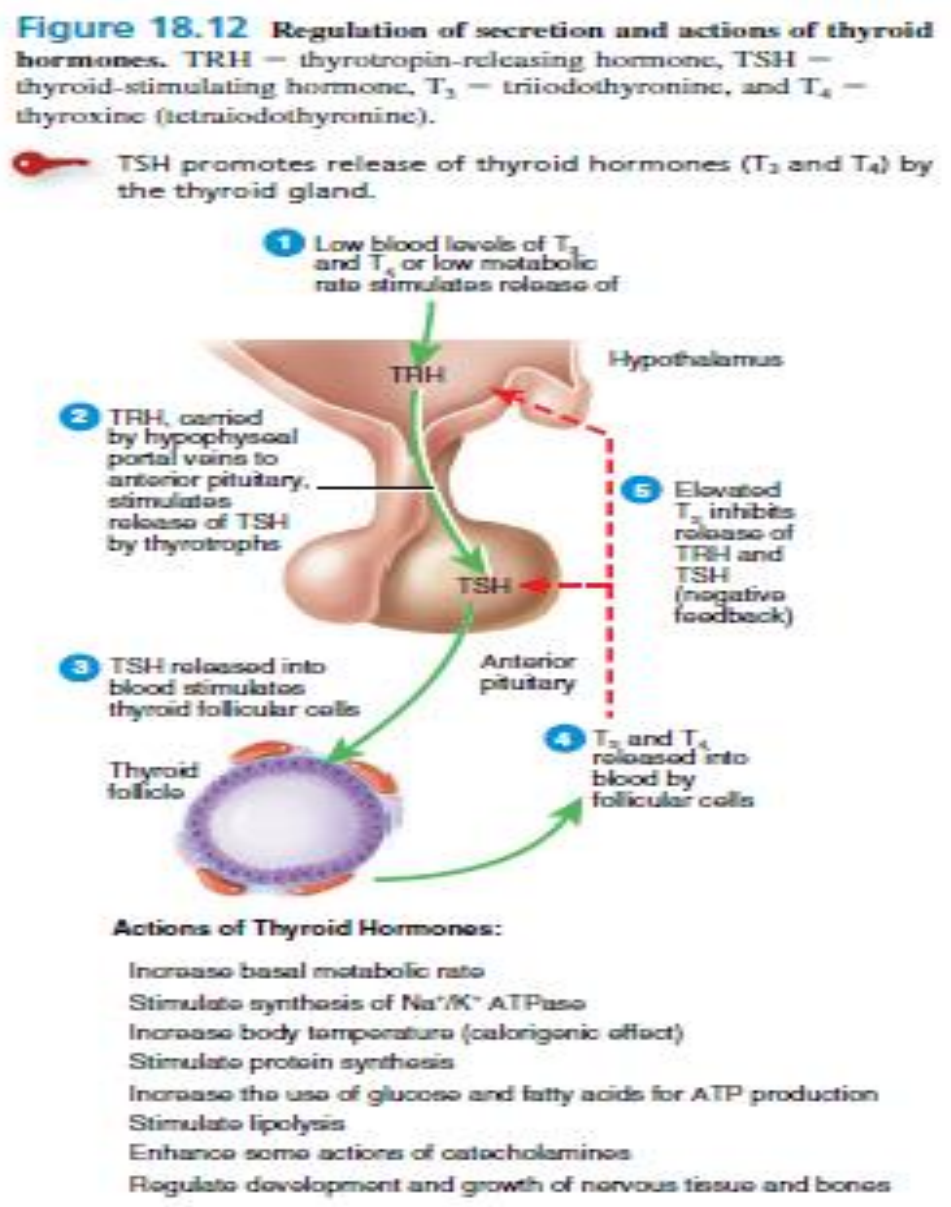

\section{calcitonin}

Hormon yang diproduksi oleh sel-sel parafollicular dari kelenjar tiroid adalah kalsitonin (CT). CT dapat menurunkan kadar kalsium dalam darah dengan menghambat aksi osteoklas, sel-sel yang memecah tulang matriks ekstraselular. Sekresi CT dikendalikan oleh sistem umpan balik negatif. 


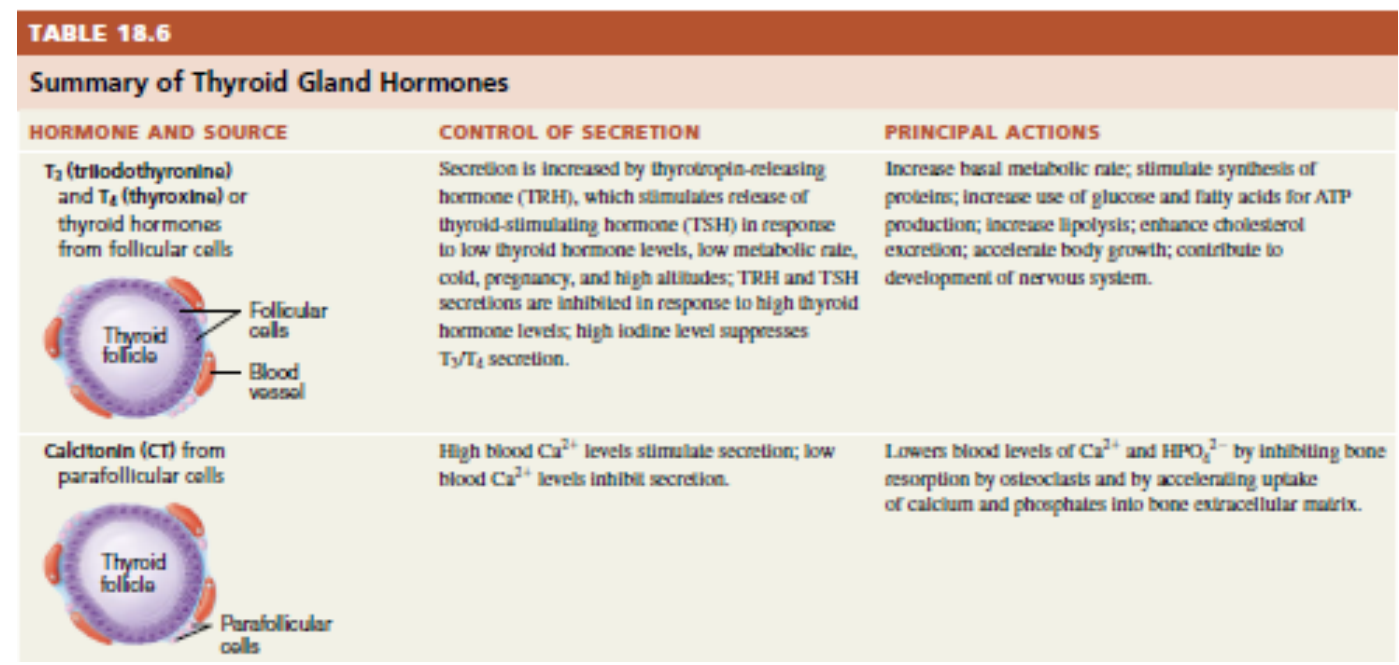

Ketika tingkat darah tinggi, kalsitonin menurunkan jumlah kalsium darah dan fosfat dengan menghambat resorpsi tulang (pemecahan tulang matriks ekstraselular) oleh osteoklas dan dengan mempercepat uptake kalsium dan fosfat ke dalam tulang matriks ekstraselular. Miacalcin, ekstrak kalsitonin yang berasal dari salmon yang 10 kali lebih kuat dari kalsitonin manusia, diresepkan untuk mengobati osteoporosis.

\section{Kelenjar Paratiroid}

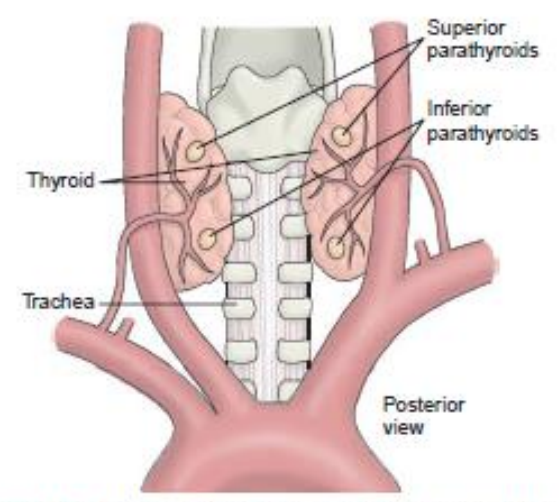

Figure 42-5 The parathyroid glands are located behind the thyroid gland. The parathyroids may be embedded in the thyroid tissue.
Kelenjar paratiroid (secara normal empat) yang terletak di leher dan melekat pada lobus lateral posterior dari kelenjar tiroid. Masing-masing memiliki massa sekitar $40 \mathrm{mg}(0,04 \mathrm{~g})$. Secara mikroskopis, kelenjar paratiroid mengandung dua jenis sel epitel (Gambar 18.13b, c). Semakin banyak sel yang disebut sel chief atau sel utama, menghasilkan hormon paratiroid (PTH), juga disebut parathormon. Fungsi dari jenis lain sel, yang disebut sel oxyphil, belum diketahui pada kelenjar paratiroid normal. Namun, kehadirannya jelas membantu untuk

mengidentifikasi kelenjar paratiroid secara histologis karena karakteristik pewarnaan yang unik. Selain itu, dalam kanker kelenjar paratiroid, oxyphil sel mensekresi kelebihan PTH.

\section{Paratiroid Hormon (PTH)}

Hormon paratiroid adalah regulator utama dari kadar kalsium $\left(\mathrm{Ca}^{2+}\right)$, magnesium $\left(\mathrm{Mg}^{2+}\right)$, dan ion fosfat $\left(\mathrm{HPO}_{4}{ }^{2-}\right)$ dalam darah. Aksi spesifik PTH adalah untuk meningkatkan jumlah dan aktivitas osteoclasts. Akibatnya ditinggikan resorpsi tulang, yang melepas kalsium ion dan fosfat ke dalam darah. PTH juga berperan pada ginjal. Pertama, memperlambat tingkat di mana $\mathrm{Ca}^{2+}$ dan $\mathrm{Mg}^{2+}$ hilang dalam darah ke dalam urin. Kedua, meningkatkan hilangnya $\mathrm{HPO}_{4}{ }^{2-}$ dari dalam darah ke dalam urin. Karena lebih $\mathrm{HPO}_{4}{ }^{2-}$ hilang dalam urin daripada yang diperoleh dari tulang, PTH menurunkan HPO4 dalam 
darah dan meningkatkan tingkat $\mathrm{Ca}^{2+}$ dan $\mathrm{Mg}^{2+}$ dalam darah. Efek ketiga PTH pada ginjal adalah untuk meningkatkan pembentukan hormon calcitriol, bentuk aktif dari vitamin D. Calcitriol, juga dikenal sebagai 1,25-dihydroxyvitamin D3, meningkatkan tingkat $\mathrm{Ca}^{2+}, \mathrm{HPO}_{4}{ }^{2-}$, dan $\mathrm{Mg}^{2+}$ absorpsi dari saluran pencernaan ke dalam darah.

Figure 18.13 Location, blood supply, and histology of the parathyroid glands.

- The parathyroid glands, normally four in number, are embedded in the posterior surface of the thyroid gland.
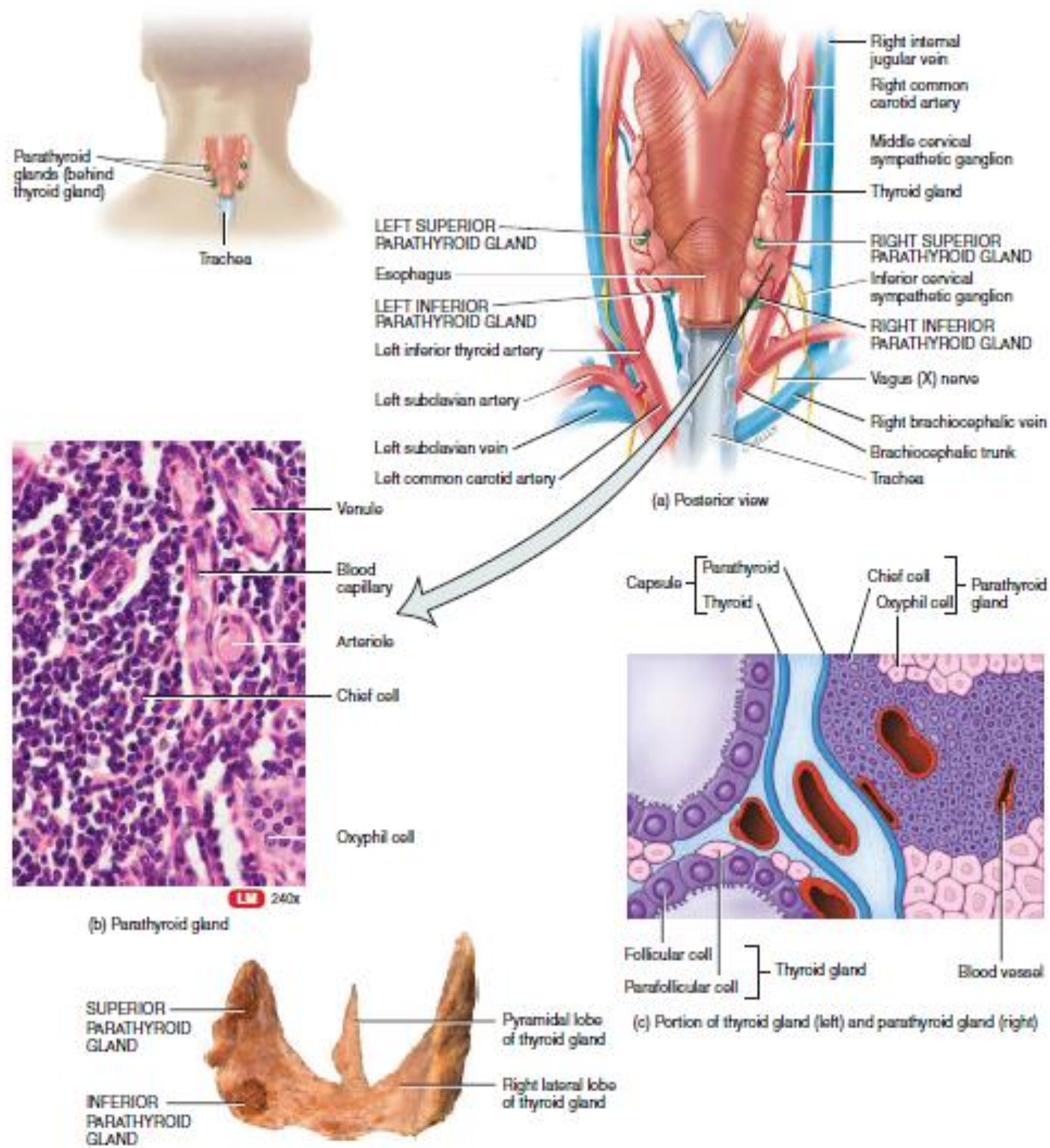

(a) Postorior viow

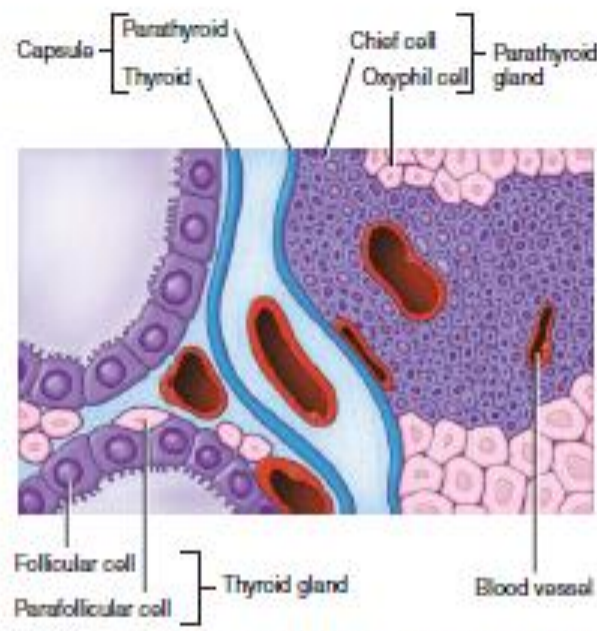

(c) Portion of thyroid gland (laft) and parafyroid gland (right)

(d) Peaterior viow of parathyrid glands 


\section{Pengendalian Sekresi Calcitonin dan paratiroid hormon}

Tingkat kalsium dalam darah secara langsung mengontrol sekresi baik kalsitonin dan hormon paratiroid melalui umpan balik negatif yang tidak melibatkan kelenjar pituitari.

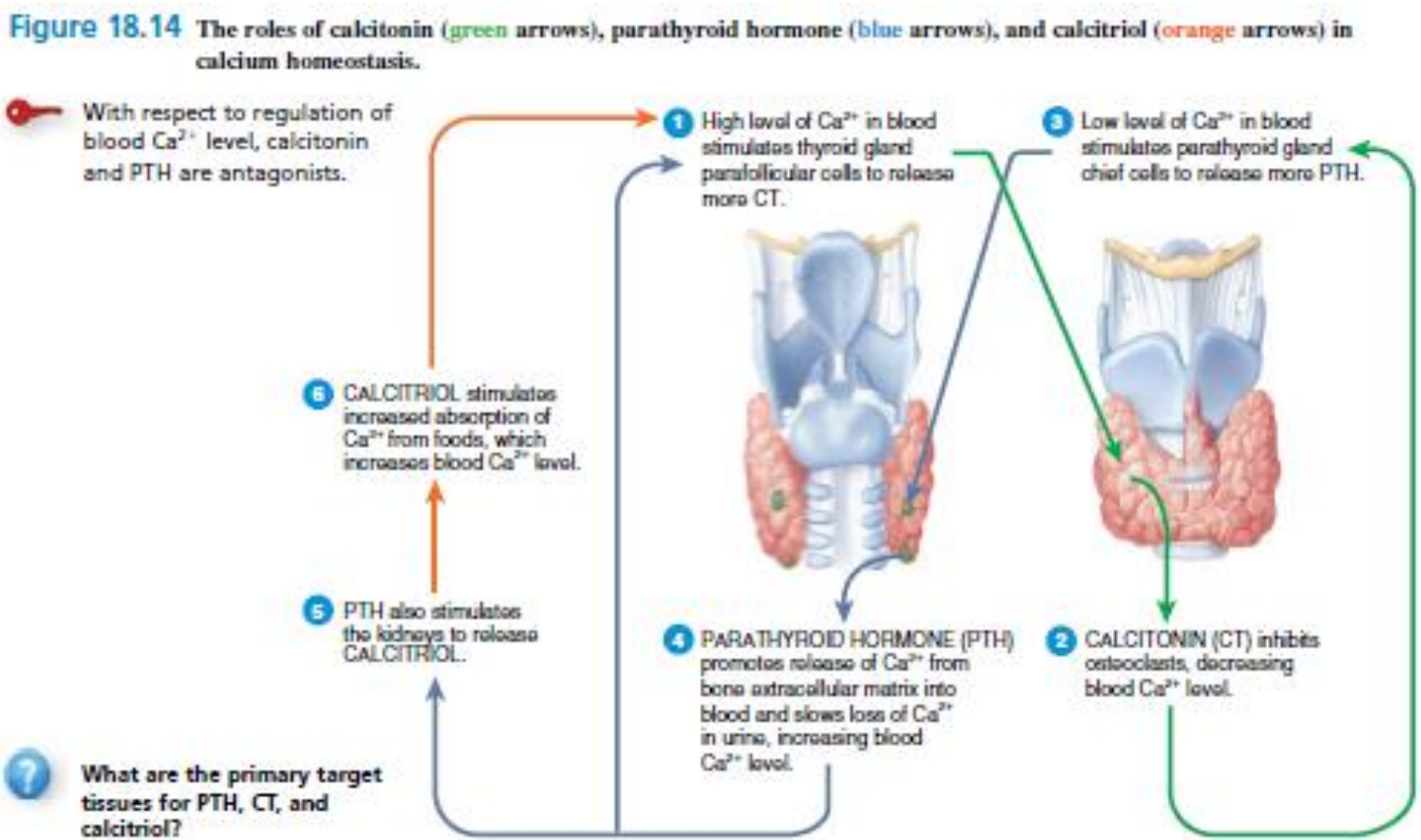

1. Suatu level yang lebih tinggi dari normal ion kalsium dalam darah menstimulasi selsel parafollicular dari kelenjar tiroid untuk melepaskan lebih banyak kalsitonin.

2. Calcitonin menghambat aktivitas osteoklas, sehingga mengurangi tingkat $\mathrm{Ca}^{2+}$ dalam darah.

3. Suatu tingkat $\mathrm{Ca}^{2+}$ yang lebih rendah dari normal dalam darah akan menstimulasi selsel utama kelenjar paratiroid untuk melepaskan lebih banyak PTH.

4. PTH mendorong resorpsi matriks ekstraselular tulang, yang melepas $\mathrm{Ca}^{2+}$ ke dalam darah dan memperlambat hilangnya $\mathrm{Ca}^{2+}$ dalam urin, untuk meningkatkan tingkat darah $\mathrm{Ca}^{2+}$

5. PTH juga merangsang ginjal untuk mensintesis calcitriol, bentuk aktif dari vitamin D.

6. Calcitriol merangsang peningkatan penyerapan $\mathrm{Ca}^{2+}$ yang berasal dari makanan di saluran pencernaan, yang akan membantu meningkatkan tingkat darah $\mathrm{Ca}^{2+}$.

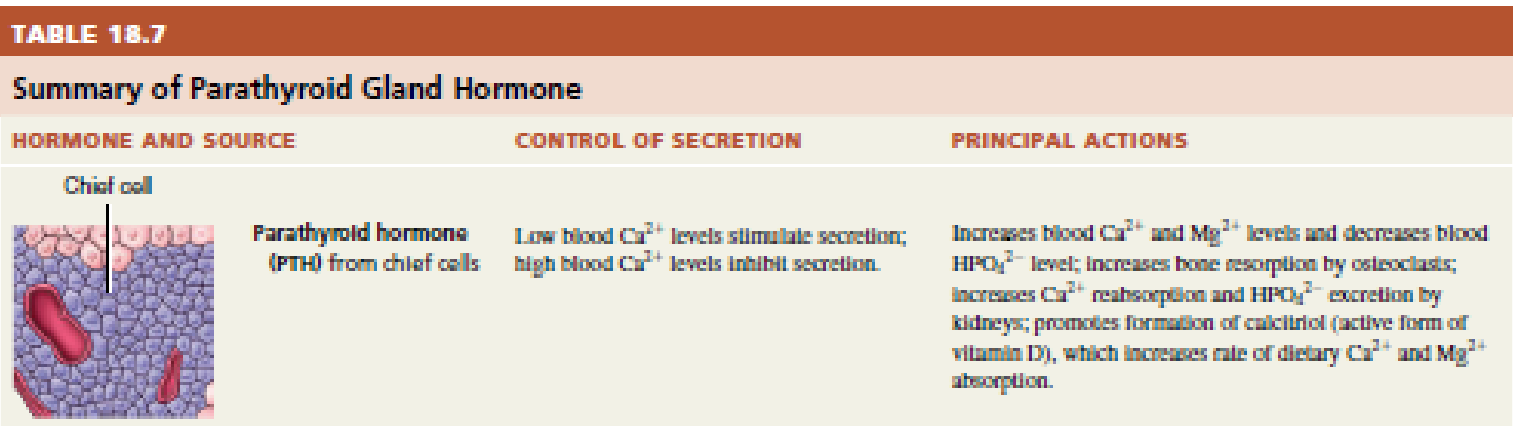




\section{Hormon Adrenal}

Kelenjar adrenal pasangan atau kelenjar suprarenal, salah satunya terletak unggul setiap ginjal di ruang retroperitoneal (Gambar 18.15a), memiliki piramida berbentuk pipih. Dalam orang dewasa, masing-masing kelenjar adrenal adalah 3-5 cm, 2-3 cm lebar, dan sedikit kurang dari $1 \mathrm{~cm}$, dengan massa 3,5-5 g, hanya setengah dari ukuran saat lahir. Selama perkembangan embrio, kelenjar adrenal berdiferensiasi menjadi dua struktural dan fungsional daerah yang berbeda: besar, perifer terletak korteks adrenal, yang terdiri dari 80-90\% dari kelenjar, dan kecil, terletak medula adrenal (Gambar 18.15b). Suatu kapsul jaringan ikat mencakup kelenjar. Kelenjar adrenal, seperti kelenjar tiroid, sangat tervaskularisasi.

Korteks adrenal menghasilkan hormon steroid yang penting bagi kehidupan. Kehilangan lengkap hormon adrenocortical menyebabkan kematian karena dehidrasi dan ketidakseimbangan elektrolit dalam beberapa hari sampai seminggu, kecuali terapi penggantian hormon dimulai segera. Adrenal medulla menghasilkan tiga katekolamin yaitu hormon norepinephrine, epinephrine, dan sejumlah kecil dopamin.

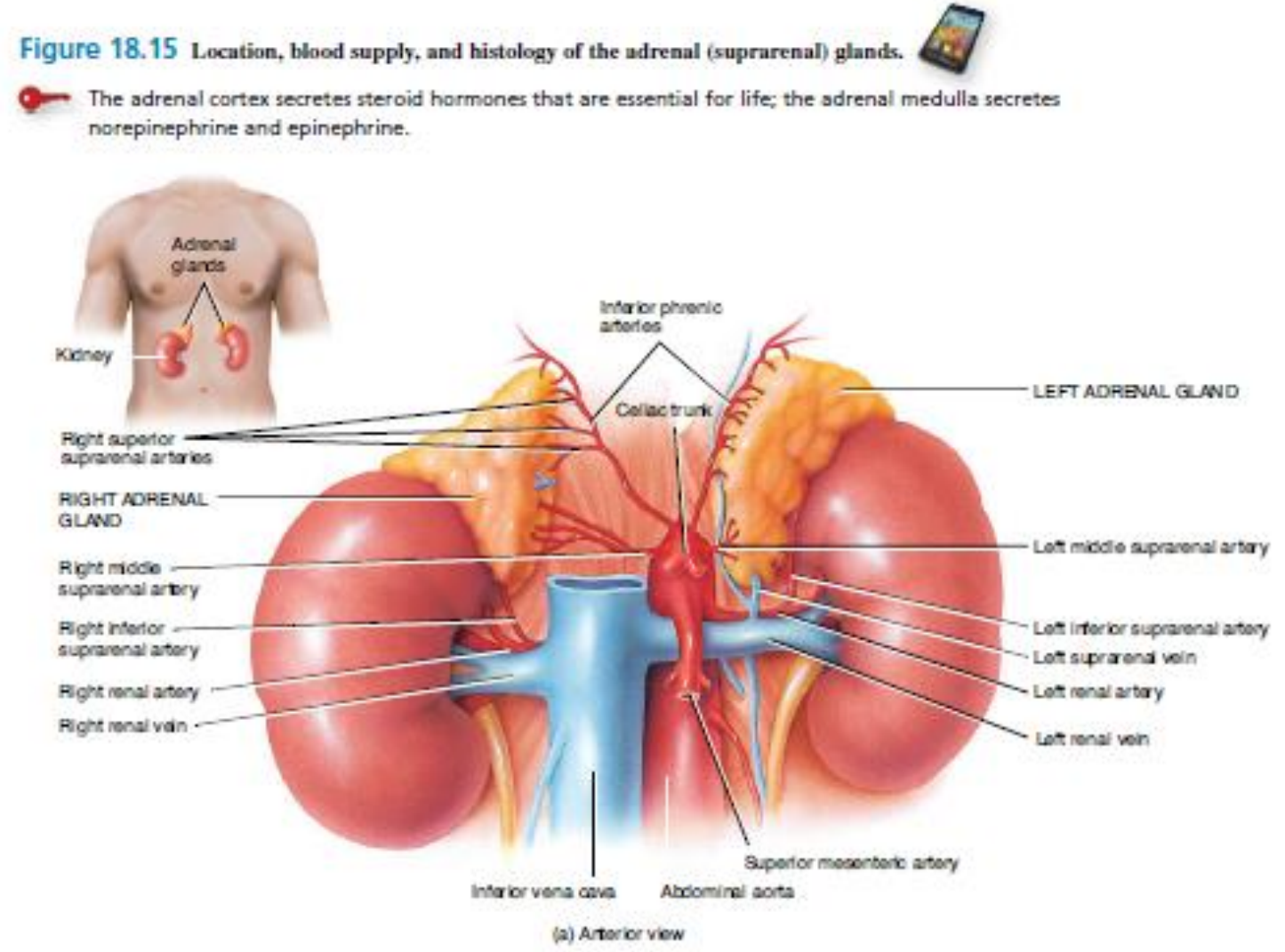

\section{Cortex adrenal}

Korteks adrenal dibagi menjadi tiga zona, masing-masing mengeluarkan hormon yang berbeda (Gambar 18.15d). Zona luar, hanya dalam untuk kapsul jaringan ikat, adalah zona glomerulosa. Sel, yang sangat erat yang dikemas dan tersusun dalam cluster berbentuk bola dan kolom yang melengkung, mensekresikan hormon yang disebut mineralocorticoids karena mereka mempengaruhi homeostasis mineral. Zona tengah, atau zona fasciculata, merupakan terluas dari tiga zona dan terdiri dari sel-sel tersusun dalam panjang, kolom lurus. Sel-sel dari zona tersebut fasciculata mensekresikan 
terutama glukokortikoid, terutama kortisol, dinamakan demikian karena mereka mempengaruhi homeostasis glukosa. Sel-sel dari zona dalam, zona reticularis, yang tersusun dalam percabangan kabel. Mereka mensintesis sejumlah kecil hormon androgen yang lemah, hormon steroid yang punya efek masculinizing.

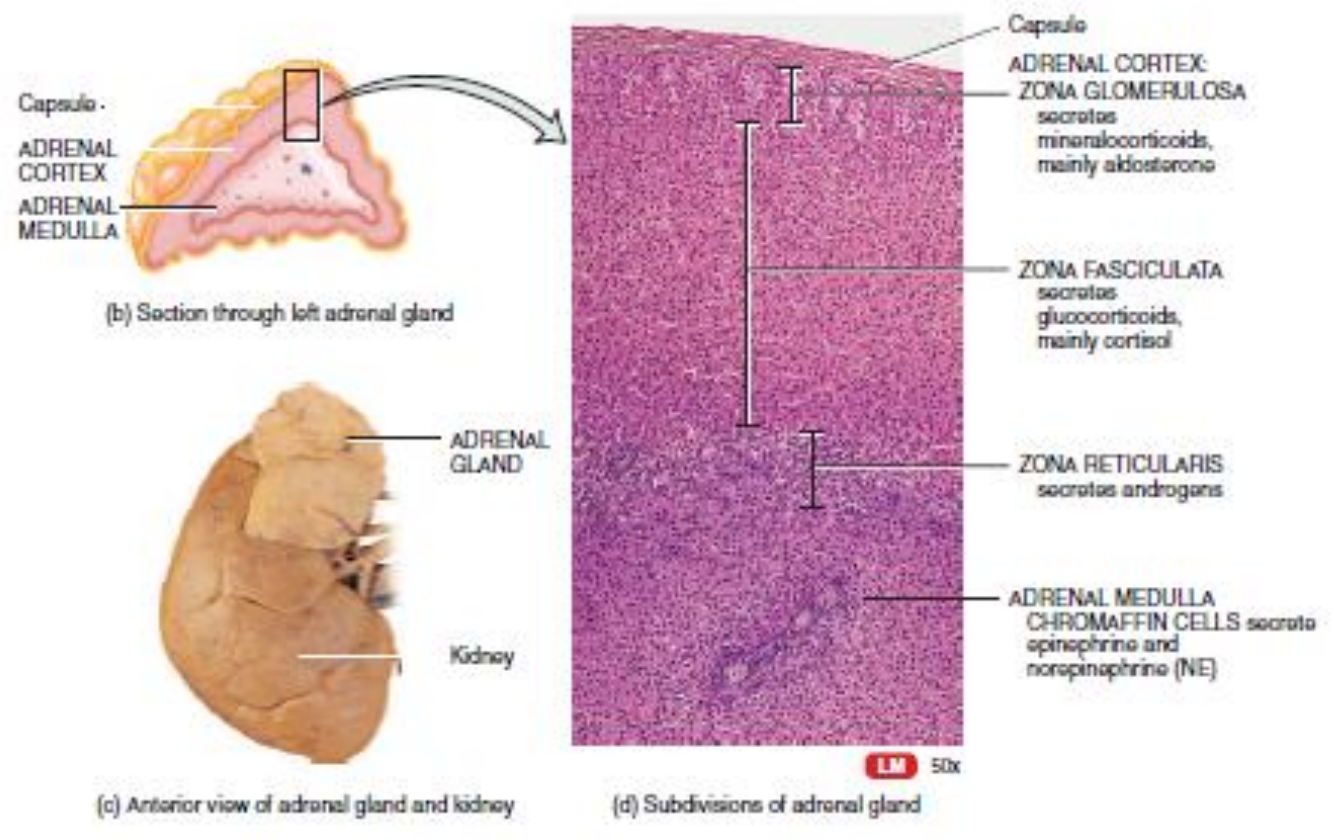

\section{Mineralokortikoid}

Aldosteron merupakan mineralokortikoid utama. Ini mengatur homeostasis dari dua ionyaitu mineral, ion natrium $\left(\mathrm{Na}^{+}\right)$Dan ion kalium $\left(\mathrm{K}^{+}\right)$Dan membantu mengatur tekanan darah dan volume darah. Aldosteron juga meningkatkan ekskresi $\mathrm{H}^{+}$dalam urin; penghapusan ini asam dari tubuh dapat membantu mencegah asidosis $(\mathrm{pH}$ darah di bawah 7.35) .

\section{Pengendalian aldosteron Sekresi}

1) Pathway Renin-angiotensin-aldosteron (RAA) mengontrol sekresi aldosteron,:

2) Stimulus yang memulai pathway renin-angiotensin-aldosteron termasuk dehidrasi, kekurangan $\mathrm{Na}+$, atau perdarahan.

3) Kondisi ini menyebabkan penurunan volume darah.

4) Penurunan volume darah menyebabkan penurunan tekanan darah.

5) Tekanan darah Menurunkan merangsang beberapa sel dari ginjal, yang disebut sel juxtaglomerular, untuk mensekresikan enzim renin.

6) Tingkat renin dalam darah meningkat.

7) Renin akan mengubah angiotensinogen, suatu protein plasma yang dihasilkan oleh hati, menjadi angiotensin I.

8) Kadar Angiotensin I dalam Darah meningkat dan beredar dalam tubuh.

9) Saat darah mengalir melalui kapiler, terutama paru-paru, enzim angiotensinconverting enzyme (ACE) mengubah angiotensin I menjadi hormon angiotensin II.

10) Tingkat angiotensin II dalam darah meningkat.

11) Angiotensin II merangsang korteks adrenal untuk mensekresikan aldosteron. 
12) Darah berisi peningkatan kadar aldosteron dan diedarkan ke ginjal

13) Di ginjal, aldosteron meningkatkan reabsorpsi Na+, yang pada akhirnya menyebabkan reabsorpsi air melalui osmosis. Akibatnya, sedikit air hilang dalam urin. Aldosteron juga merangsang ginjal untuk meningkatkan sekresi $\mathrm{K}+\mathrm{dan} \mathrm{H}+$ ke dalam urin.

14) Dengan meningkatnya reabsorpsi air oleh ginjal, volume darah meningkat.

15) Seiring dengan peningkatan volume darah, tekanan darah meningkat dari normal.

16) Angiotensin II juga merangsang kontraksi otot polos di dinding arteriol. Vasokonstriksi yang dihasilkan dari arteriol meningkatkan tekanan darah dan dengan demikian membantu meningkatkan tekanan darah dari normal.

17) Selain angiotensin II, stimulator yang kedua sekresi aldosteron adalah peningkatan $\mathrm{K}+$ dalam darah (atau cairan interstitial). Penurunan tingkat $\mathrm{K}+$ darah memiliki dampak sebaliknya.

Figure 18.16 Regulation of aldosterone secretion by the renin-angiotensin-aldosterone (RAA) pathway.

Aldosterone helps regulate blood volume, blood pressure, and levels of $\mathrm{Na}^{+}, \mathrm{K}^{+}$, and $\mathrm{H}^{+}$in the blood.
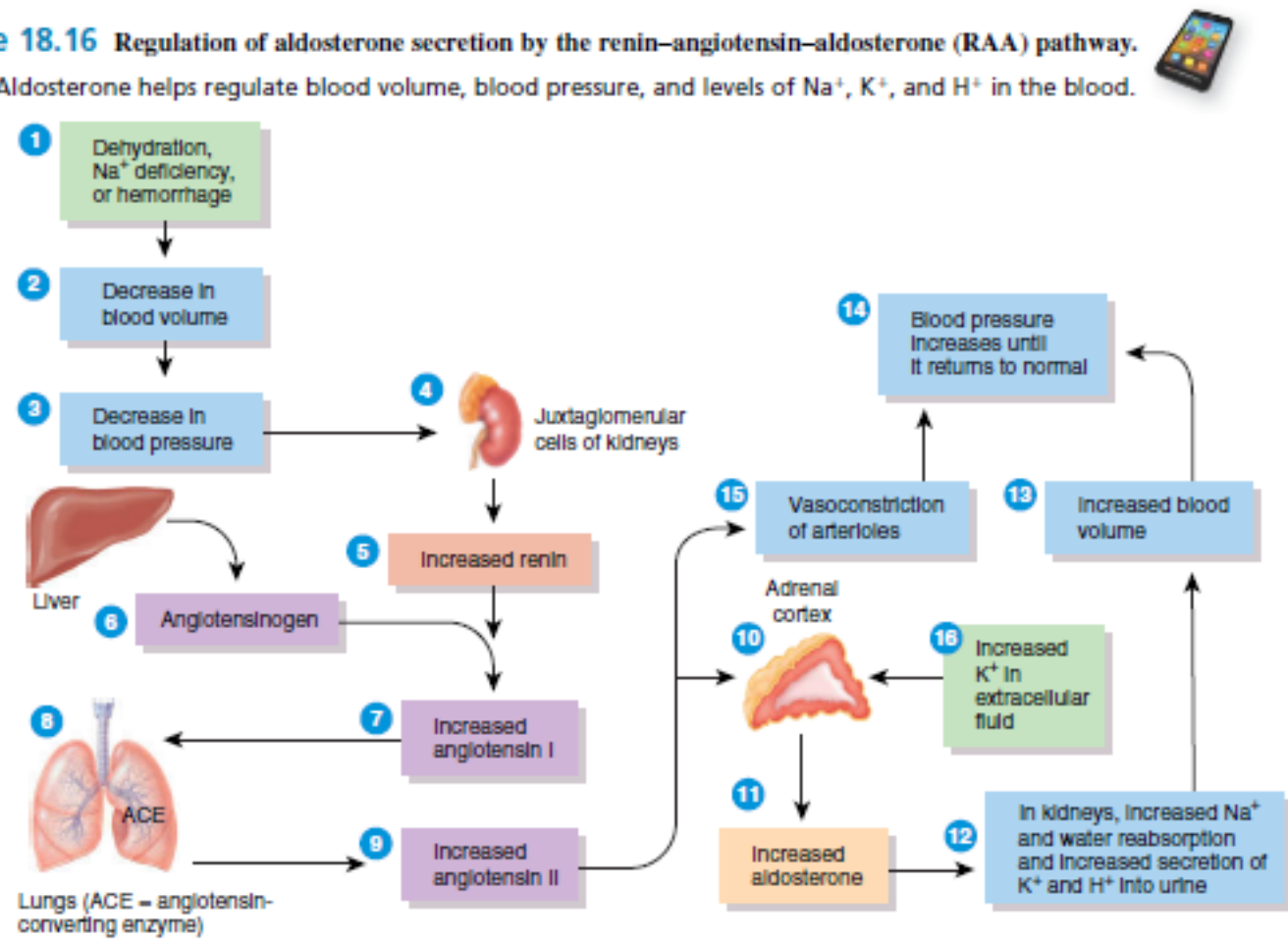

\section{Glukokortikoid}

glukokortikoid, dimana mengatur metabolisme tubuh dan daya tahan terhadap stres, termasuk kortisol (juga disebut hidrokortison), kortikosteron, dan kortison. Dari ketiga hormon ini disekresi oleh zona fasciculata, kortisol yang paling banyak, terhitung sekitar 95\% dari aktivitas glukokortikoid. Glukokortikoid memiliki efek sebagai berikut:

1) Pemecahan protein. Glukokortikoid meningkatkan kecepatan pemecahan protein, terutama dalam serat otot, dan dengan demikian meningkatkan pembebasan asam amino ke dalam aliran darah. Asam amino dapat digunakan oleh sel-sel tubuh untuk sintesis protein baru atau untuk memproduksi ATP. 
2) pembentukan glukosa. Pada stimulasi oleh glukokortikoid, sel-sel hati dapat mengkonversi asam amino tertentu atau asam laktat menjadi glukosa, yang neuron dan sel-sel lain dapat digunakan untuk produksi ATP. Konversi yang terjadi dari zat selain glikogen atau monosakarida lain menjadi glukosa disebut glukoneogenesis.

3) Lipolisis. Glukokortikoid merangsang lipolisis, pemecahan trigliserida dan pelepasan asam lemak dari jaringan adiposa ke dalam darah.

4) Daya tahan terhadap stress. Kerja glukokortikoid dengan berbagai cara untuk memberikan ketahanan terhadap stres. Glukosa tambahan yang disediakan oleh sel-sel hati menyediakan jaringan dengan sumber penyediaan ATP untuk mengatasi berbagai stres, termasuk olahraga, puasa, ketakutan, suhu ekstrim, ketinggian, perdarahan, infeksi, operasi, trauma, dan penyakit. Karena glukokortikoid membuat pembuluh darah lebih sensitif terhadap hormon lain yang menyebabkan vasokonstriksi, mereka meningkatkan tekanan darah. Efek ini akan menjadi keuntungan dalam kasus kehilangan darah yang parah, yang menyebabkan tekanan darah turun.

5) Efek anti-inflamasi. Glukokortikoid menghambat sel darah putih yang berpartisipasi dalam respon inflamasi. Sayangnya, glukokortikoid juga memperlambat perbaikan jaringan; akibatnya, mereka memperlambat penyembuhan luka. Meskipun dosis tinggi dapat menyebabkan gangguan mental yang berat, glukokortikoid sangat berguna dalam pengobatan gangguan inflamasi yang kronis seperti rheumatoid arthritis.

6) Depresi respon imun. Dosis tinggi glukokortikoid menekan respon imun. Karena suatu alasan ini, glukokortikoid diresepkan untuk penerima transplantasi organ untuk menghambat penolakan jaringan tubuh oleh sistem kekebalan tubuh.

Figure 18.17 Negative feedback regulation of glucocorticoid secretion.

- A high level of CRH and a low level of glucocorticoids promote the release of ACTH, which stimulates

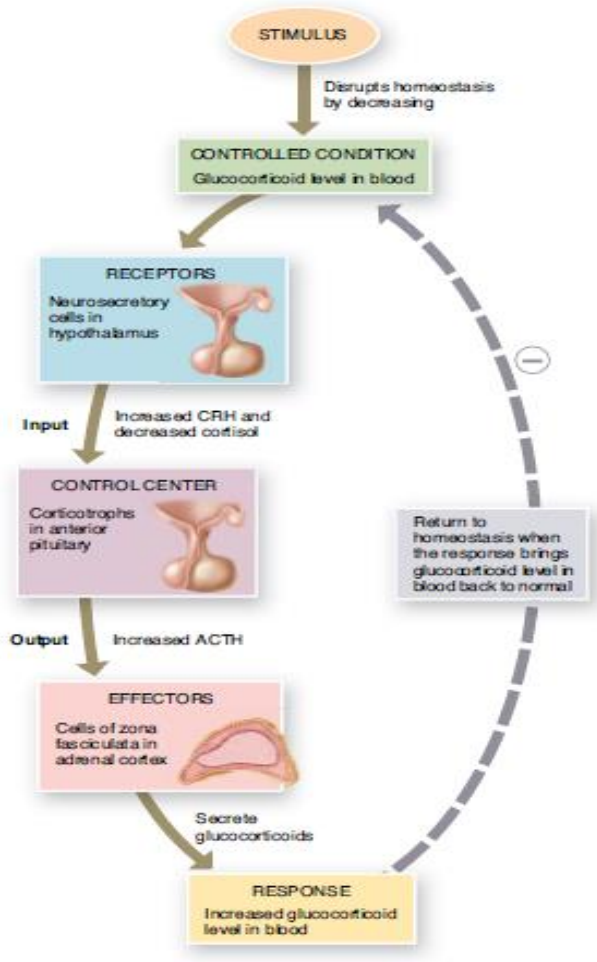

\section{Kontrol glukokortikoid Sekresi}

Kontrol sekresi glukokortikoid terjadi melalui sistem umpan balik negatif yang khas (Gambar 18.17). Tingkat glukokortikoid rendah dalam darah, terutama kortisol, merangsang sel neurosecretory di hipotalamus untuk mensekresikan corticotropin-releasing hormone (CRH). CRH (bersama-sama dengan rendahnya kortisol) mendorong pelepasan ACTH dari hipofisis anterior. ACTH mengalir dalam darah ke korteks adrenal, dimana merangsang sekresi glukokortikoid. (Untuk tingkat yang jauh yang lebih kecil, ACTH juga merangsang sekresi aldosteron.) 


\section{Androgen}

Baik laki-laki dan perempuan, korteks adrenal mengeluarkan dalam jumlah kecil hormon androgen yang lemah. Androgen yang utama yang disekresi oleh kelenjar adrenal adalah dehydroepiandrosterone (DHEA). Setelah masa pubertas pada lakilaki, testosteron androgen juga dirilis dalam jumlah yang jauh lebih besar oleh testis. Dengan demikian, jumlah hormon androgen disekresikan oleh kelenjar adrenal pada laki-laki umumnya sangat rendah sehingga efeknya tidak signifikan. Pada wanita, bagaimanapun, hormon androgen adrenal memainkan peran penting. Mereka meningkatkan libido (sex drive) dan diubah menjadi estrogen (feminisasi steroid seks) oleh jaringan tubuh lainnya. Setelah menopause, ketika sekresi estrogen ovarium berhenti, semua estrogen wanita berasal dari konversi hormon androgen adrenal. hormon androgen adrenal juga merangsang pertumbuhan ketiak dan rambut kemaluan pada anak laki dan perempuan dan memberikan kontribusi pada percepatan pertumbuhan prapubertas. Meskipun kontrol sekresi androgen adrenal tidak sepenuhnya diketahui, hormon utama yang merangsang sekresi adalah ACTH.

\section{Adrenal Medulla}

Daerah dalam dari kelenjar adrenal, medula adrenal, adalah ganglion simpatik yang dimodifikasi dari sistem saraf otonom (ANS). Ini berkembang dari jaringan embrio yang sama seperti semua ganglia simpatik lainnya, tetapi sel-sel, yang tidak memiliki akson, cluster bentuk sekitar pembuluh darah besar. Daripada merilis neurotransmitter, sel-sel medula adrenal mensekresikan hormon. Sel-sel penghasil hormon, yang disebut sel chromaffin (lihat Gambar 18.15d), dipersarafi oleh neuron preganglionik simpatis dari ANS tersebut. Karena ANS memberikan kontrol langsung terhadap sel-sel chromaffin, pelepasan hormon dapat terjadi sangat cepat.

Dua hormon utama disintesis oleh medula adrenal adalah epinefrin dan norepinefrin (NE), juga disebut adrenalin dan noradrenalin, masing-masing. Sel-sel chromaffin dari medula adrenal mensekresikan jumlah hormon yang tidak merata sekitar $80 \%$ epinefrin dan norepinefrin 20\%. Hormon dari medula adrenal meningkatkan respon simpatik yang terjadi di bagian lain dari tubuh.

\section{Kontrol Sekresi epinefrin dan norepinefrin}

Dalam situasi stres dan selama latihan, impuls dari hipotalamus merangsang neuron preganglionik simpatis, yang pada akhirnya merangsang sel-sel chromaffin untuk mensekresikan epinefrin dan norepinefrin. Kedua hormon sangat meningkatkan respon fight-or-flight. Dengan cara meningkatkan denyut jantung dan kekuatan 
kontraksi, epinefrin dan norepinefrin meningkatkan Output dari jantung, sehingga meningkatkan tekanan darah. Mereka juga meningkatkan aliran darah ke jantung, liver, otot rangka, dan jaringan adiposa; melebarkan saluran udara ke paru-paru; dan meningkatkan kadar glukosa dan asam lemak.

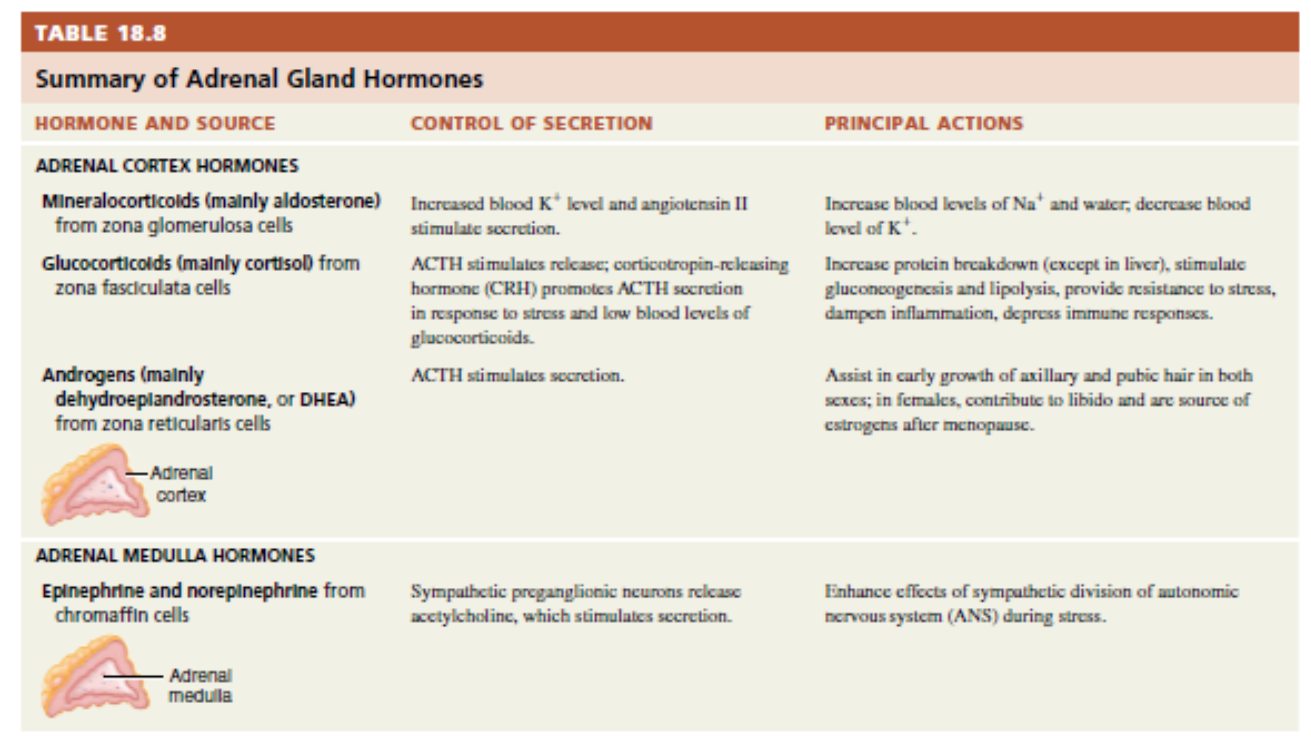

\section{Pankreas Islets}

Pankreas adalah kelenjar endokrin dan kelenjar eksokrin. bahasan di sini fungsi endokrin Suatu organ pipih yang Panjangnya sekitar 12,5-15 cm (5-6 in.), pankreas berlokasi di lekukan duodenum, bagian pertama dari usus kecil, dan terdiri dari kepala, tubuh, dan ekor (Gambar 18.18a), Sekitar 99\% dari sel-sel eksokrin pankreas disusun dalam kelompok yang disebut asinus. Asinus menghasilkan enzim pencernaan, dimana mengalir ke saluran pencernaan melalui jaringan duktus. Tersebar di antara asinus eksokrin yang 1-2 juta cluster kecil jaringan endokrin yang disebut pulau pankreas (Ilets) atau pulau Langerhans (Gambar 18.18b, c). Kapiler berlimpah bermanfaat baik untuk eksokrin dan endokrin bagian dari pankreas. 


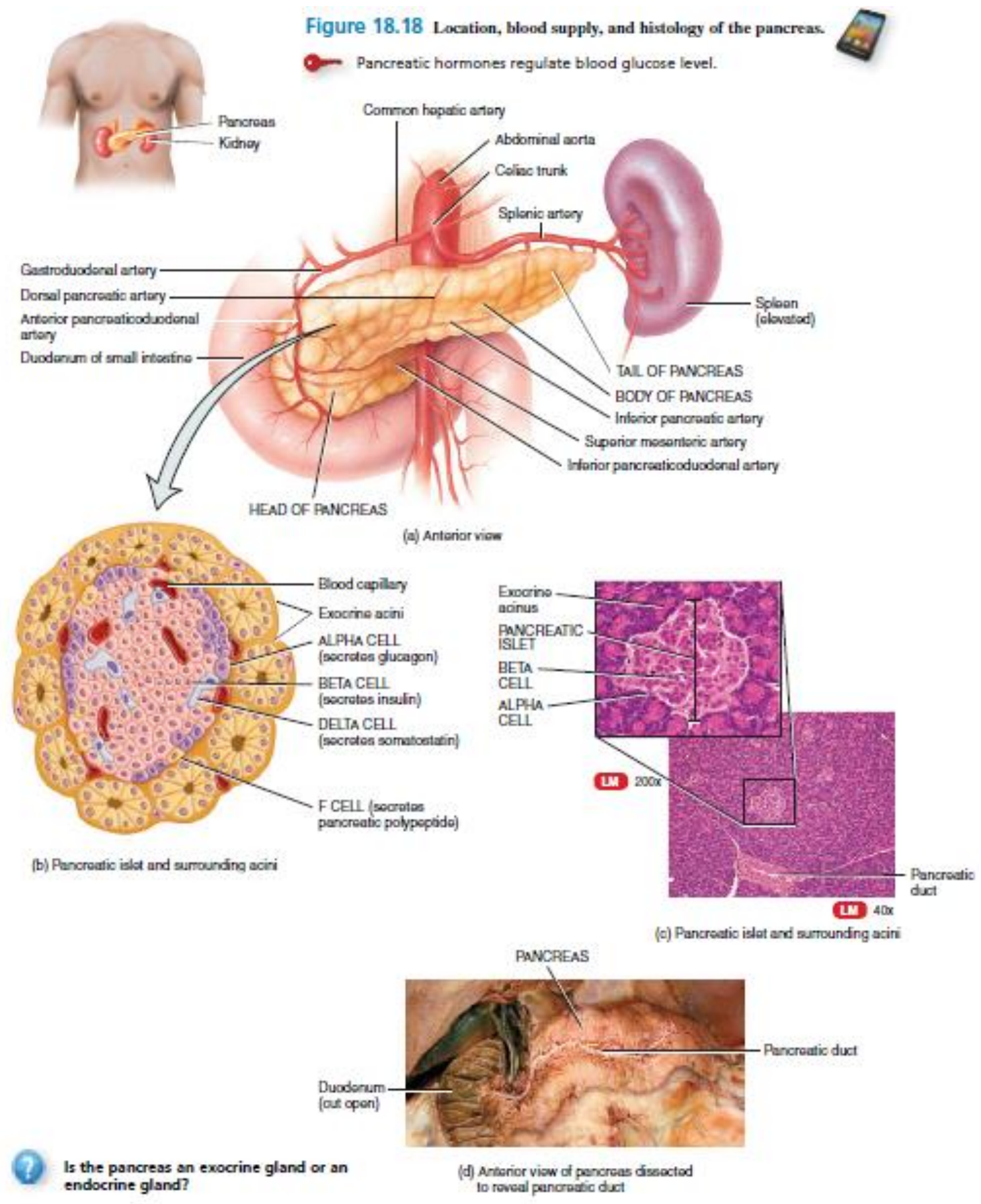

\section{Jenis sel di pankreas Islets}

Setiap pulau pankreas meliputi empat jenis sel yang mensekresi hormon:

1) Alpha atau Suatu sel mencakup sekitar $17 \%$ dari sel-sel islet pankreas dan mensekresikan glukagon.

2) Beta atau B sel mencakup sekitar $70 \%$ dari sel-sel islet pankreas dan mensekresikan insulin

3) Delta atau D sel mencakup sekitar $7 \%$ dari sel islet pankreas dan mensekresikan somatostatin

4) sel F merupakan sisa sel islet pankreas dan mensekresikan polipeptida pankreas 
Interaksi dari empat hormon pankreas merupakan yang kompleks dan tidak sepenuhnya dipahami. Kita tahu bahwa glukagon meningkatkan kadar glukosa darah, dan insulin menurunkan. Tindakan somatostatin secara parakrin untuk menghambat baik rilis insulin dan glukagon dari sekitarsel beta dan alpha. Hal ini juga dapat bertindak sebagai hormon yang beredar untuk memperlambat penyerapan nutrisi dari saluran pencernaan. Selain itu, somatostatin menghambat sekresi growth hormone. Polipeptida pankreas menghambat sekresi somatostatin, kontraksi kandung empedu, dan sekresi enzim pencernaan oleh pankreas.

\section{Kontrol Sekresi Glukagon dan Insulin}

Figure 18.19 Negative feedback regulation of the secretion of glucagon (blue arrows) and insulin (orange arrows).

Low blood glucose stimulates release of glucagon; high blood glucose stimulates secretion of insulin.

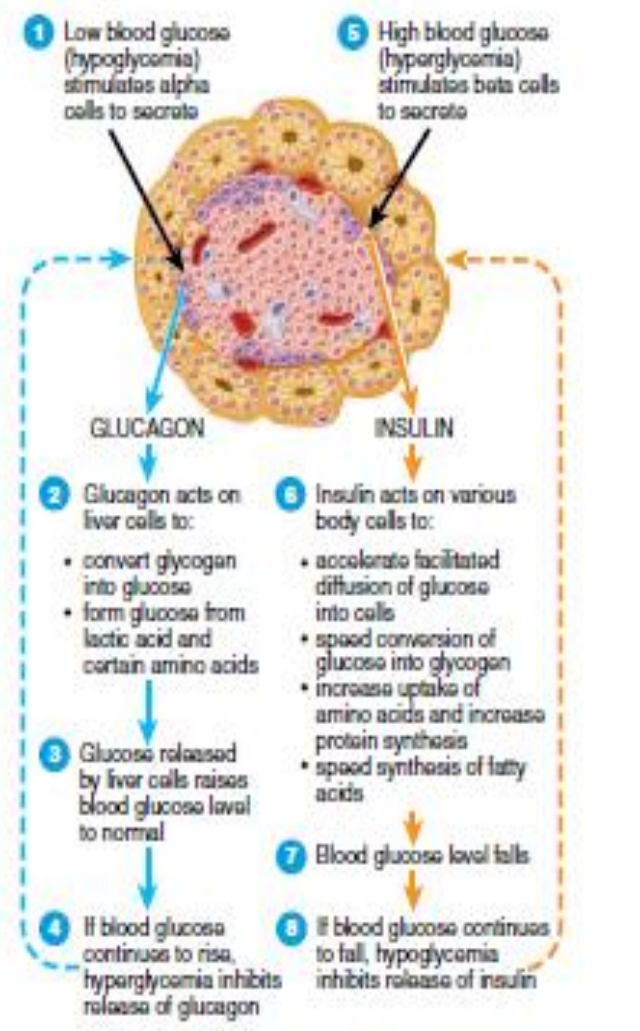

Aksi utama glukagon adalah untuk meningkatkan kadar glukosa darah ketika turun di bawah normal. Insulin, sebaliknya, membantu kadar gula darah saat terlalu tinggi. Tingkat glukosa dalam darah mengontrol sekresi glukagon dan insulin melalui umpan balik negatif (Gambar 18.19):

1) Kadar gula dalam darah rendah (hipoglikemia) merangsang sekresi glukagon dari sel alfa pulau pankreas.

2) Glukagon bekerja pada hepatosit (sel hati) untuk mempercepat konversi glikogen menjadi glukosa (glikogenolisis) dan untuk meningkatkan pembentukan glukosa dari asam laktat dan asam amino tertentu (glukoneogenesis).

3) Akibatnya, hepatosit glukosa rilis ke dalam darah lebih cepat, dan kadar gula darah naik.

4) Jika glukosa darah terus meningkat, kadar gula darah tinggi (hiperglikemia) menghambat pelepasan glukagon (umpan balik negatif).

5) Glukosa darah tinggi (hiperglikemia) menstimulasi sekresi insulin oleh sel beta pankreas.

6) Tindakan insulin pada berbagai sel dalam tubuh untuk mempercepat Memfasilitasi difusi glukosa ke dalam sel; untuk mempercepat konversi glukosa menjadi glikogen (glikogenesis); untuk meningkatkan penyerapan asam amino oleh sel-sel dan meningkatkan sintesis protein; untuk sintesis kecepatan asam lemak (lipogenesis); untuk memperlambat konversi glikogen menjadi glukosa (glikogenolisis); dan untuk 
memperlambat pembentukan glukosa dari asam laktat dan asam amino (glukoneogenesis).

7) Akibatnya, kadar glukosa darah turun.

8) Jika Kadar gula dalam darah turun di bawah normal, glukosa darah rendah menghambat pelepasan insulin (umpan balik negatif) dan menstimulasi pelepasan glukagon.

Walaupun Kadar gula dalam darah merupakan regulator yang paling penting dari insulin dan glukagon, beberapa hormon dan neurotransmiter juga mengatur pelepasan kedua hormon tersebut. Selain tanggapan terhadap Kadar gula dalam darah yang baru saja dijelaskan, glukagon menstimulasi pelepasan insulin secara langsung; insulin memiliki efek sebaliknya, menekan sekresi glukagon. Sebagai penurunan Kadar gula dalam darah dan insulin yang kurang dikeluarkan, sel-sel alfa pankreas yang dirilis dari efek penghambatan insulin sehingga mereka dapat mensekresikan lebih glukagon. Secara tidak langsung, human growth hormone $(\mathrm{hGH})$ dan hormon adrenokortikotropik $(\mathrm{ACTH})$ merangsang sekresi insulin karena mereka bertindak untuk meningkatkan glukosa darah.

Sekresi insulin juga dirangsang oleh:

1) Asetilkolin, neurotransmitter yang dibebaskan dari terminal akson dari serabut saraf vagus parasimpatis yang mempersarafi pulau pankreas

2) Asam amino arginin dan leusin, dimana akan hadir dalam darah pada tingkat yang lebih tinggi setelah protein yang mengandung makanan

3) Glucose-dependen insulinotropic peptida (GIP), * hormon yang dilepaskan oleh selsel enteroendokrin dari usus kecil

* GIP-yang sebelumnya disebut gaster inhibitor peptida-berganti nama karena pada konsentrasi fisiologis efek inhibitor pada fungsi lambung diabaikan. sebagai respons terhadap adanya glukosa dalam saluran pencernaan.

Dengan demikian, proses pencernaan dan penyerapan makanan yang mengandung karbohidrat dan protein memberikan stimulasi yang kuat untuk pelepasan insulin. Sekresi glukagon dirangsang oleh:

1) Peningkatan aktivitas dari simpatik dari ANS, seperti yang terjadi selama latihan

2) Kenaikan asam amino dalam darah jika Kadar gula dalam darah rendah, dimana dapat terjadi setelah makan yang berisikan protein utamanya. 


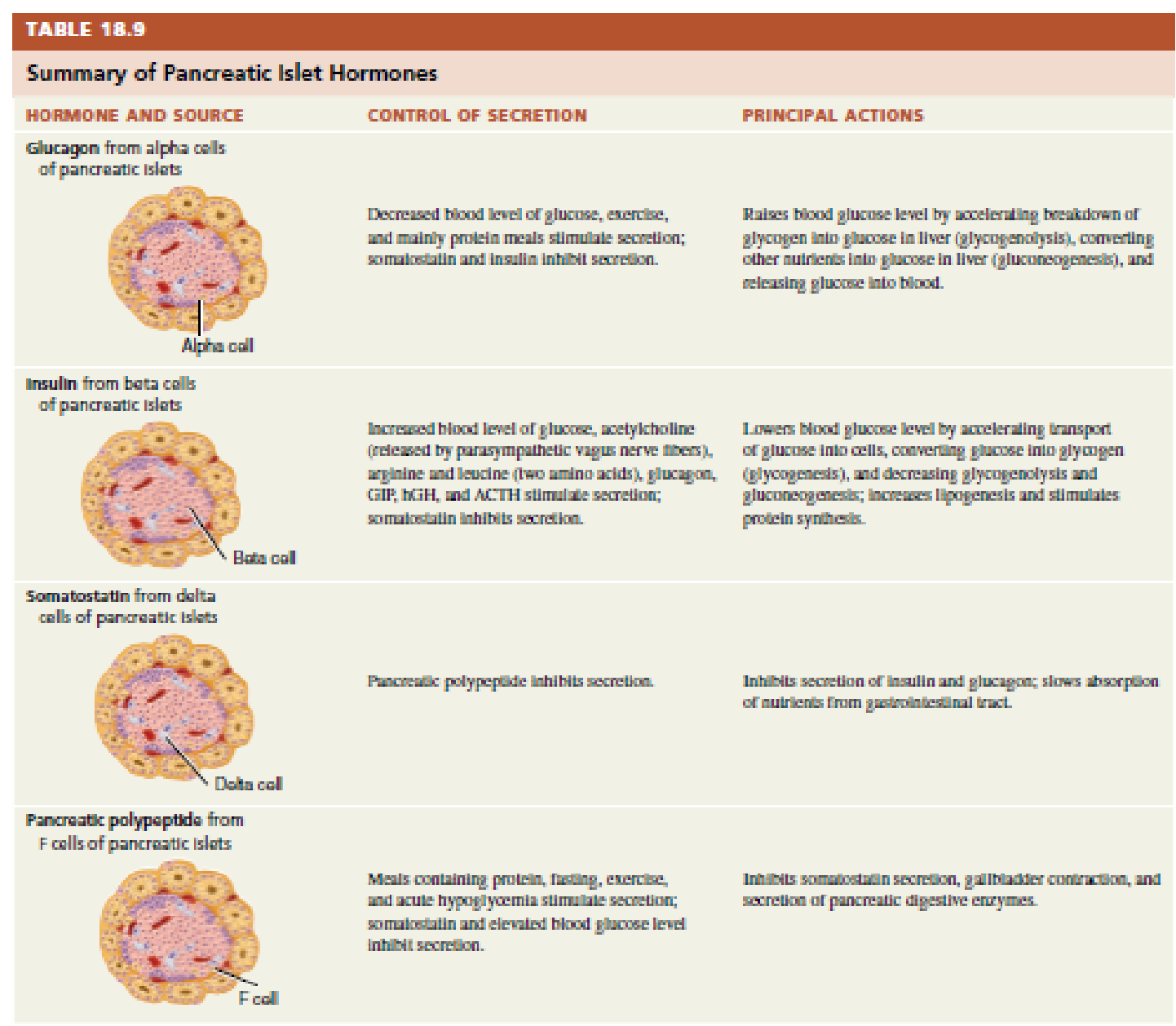

\section{Ovarium dan Testis}

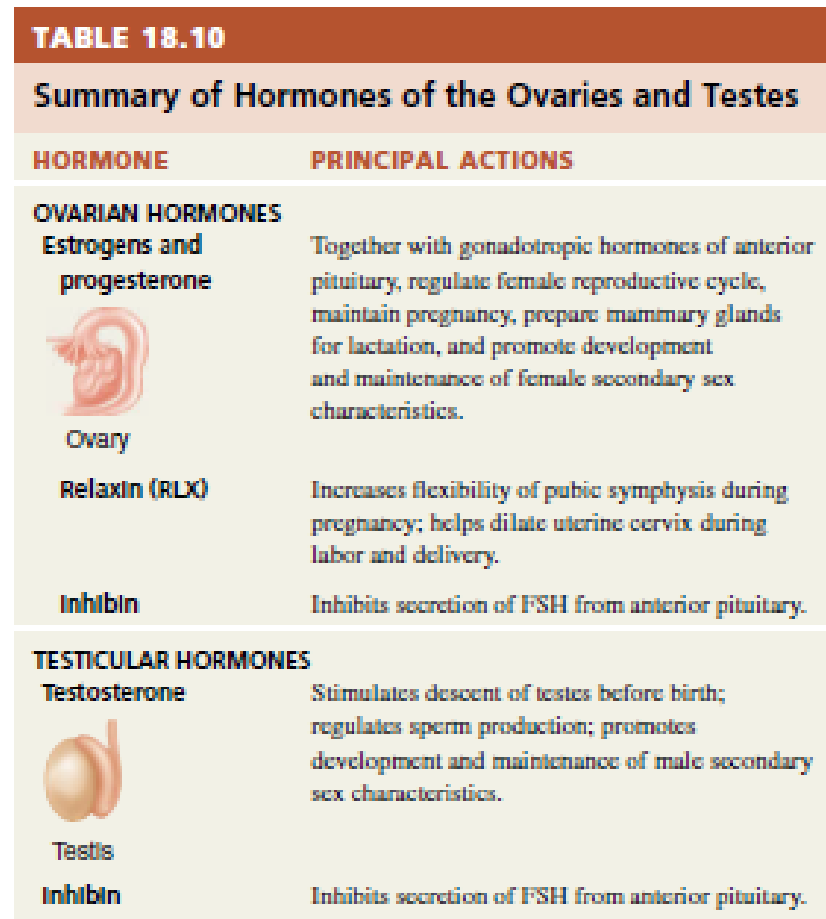

Gonad adalah organ yang memproduksi gamet-sperma pada laki-laki dan oosit pada wanita. Selain fungsi reproduksi mereka, gonad mengeluarkan hormon. Ovarium, berpasangan tubuh berbentuk oval yang terletak di dalam rongga panggul perempuan, memproduksi beberapa hormon steroid, termasuk kedua estrogen (estradiol dan estron) dan progesteron. Hormon seks wanita ini, bersama dengan folliclestimulating hormone (FSH) dan luteinizing hormone ( $\mathrm{LH})$ dari hipofisis anterior, mengatur siklus menstruasi, menjaga kehamilan, dan mempersiapkan kelenjar susu untuk menyusui. Mereka juga meningkatkan pembesaran payudara dan pelebaran pinggul saat pubertas, dan membantu menjaga karakteristik seks sekunder perempuan. 
Ovarium juga memproduksi inhibin, hormon protein yang menghambat sekresi FSH. Selama kehamilan, ovarium dan plasenta menghasilkan hormon peptida yang disebut relaksin (RLX), sehingga meningkatkan fleksibilitas simfisis pubis selama kehamilan dan membantu melebarkan serviks uterus selama persalinan dan melahirkan. Tindakan ini membantu meringankan bagian bayi dengan memperbesar jalan lahir.

Pada gonad laki-laki, testis, merupakan kelenjar berbentuk oval yang terletak di skrotum. Hormon utama yang dihasilkan dan disekresi oleh testis adalah testosteron, merupakan androgen atau hormon seks pria. Testosteron menstimulasi turunnya testis sebelum kelahiran, mengatur produksi sperma, dan menstimulasi perkembangan dan pemeliharaan karakteristik seks sekunder laki-laki, seperti pertumbuhan janggut dan pendalaman suara. Testis juga memproduksi inhibin, dimana menghambat sekresi FSH.

10. Kelenjar Pineal Thymus

Kelenjar pineal merupakan kelenjar endokrin yang kecil menempel pada atap dalam ventrikel sepertiga pada midline otak (lihat Gambar 18.1). Bagian dari epithalamus, posisi di antara kedua colliculi superior, memiliki massa 0.1-0.2 g, dan ditutupi oleh kapsul terbentuk dari pia mater. Kelenjar ini terdiri dari massa neuroglia dan sel sekretori disebut pinealocytes.

Kelenjar pineal mengeluarkan melatonin, hormon amina yang berasal dari serotonin. Melatonin muncul untuk berkontribusi pada pengaturan jam biologis tubuh, yang dikendalikan oleh inti suprachiasmatic hipotalamus. Karena semakin banyak melatonin dibebaskan selama gelap gulita daripada cahaya, hormon ini diduga untuk meningkatkan rasa kantuk. Sebagai respons terhadap input visual dari mata (retina), inti suprachiasmatic menstimulasi neuron postganglionik simpatik dari ganglion cervical superior, yang pada akhirnya merangsang pinealocytes kelenjar pineal untuk mensekresikan melatonin dengan pola berirama, dengan rendahnya tingkat melatonin disekresikan pada saat hari dan tingkat signifikan lebih tinggi disekresikan pada malam hari. Selama tidur, kadar plasma dari melatonin meningkat sepuluh kali lipat dan kemudian menurun ke tingkat yang rendah lagi sebelum kebangkitan. Dosis kecil melatonin yang diberikan secara oral dapat menginduksi tidur dan reset irama harian, yang mungkin akan bermanfaat bagi pekerja yang bergantian shift antara siang hari dan malam hari jam. Melatonin juga merupakan antioxidant yang potensial dapat memberikan perlindungan terhadap oksigen yang merusak radikal bebas.

Pada hewan yang berkembang biak selama musim tertentu, melatonin menghambat fungsi reproduksi, namun belum jelas apakah melatonin mempengaruhi fungsi reproduksi manusia. Tingkat melatonin berada lebih tinggi pada anak-anak dan menurun dengan usia menjadi dewasa, tetapi tidak ada bukti bahwa perubahan sekresi melatonin berhubungan dengan masa pubertas dan pematangan seksual. Namun demikian, karena melatonin menyebabkan atrofi gonad pada beberapa spesies hewan, kemungkinan efek samping pada reproduksi manusia harus dipelajari sebelum digunakan untuk mereset irama keseharian dapat dianjurkan.

Timus ini terletak di belakang tulang dada antara paru-paru. Karena peran timus dalam kekebalan. Hormon yang dihasilkan oleh thymus-thymosin, thymus-humoral-factor (THF), thymus-factor (TF), dan thymopoietin -Mempromosikan pematangan sel $\mathrm{T}$ 
(sejenis sel darah putih yang menghancurkan mikroba dan zat asing) dan dapat memperlambat proses penuaan.

\section{DAFTAR PUSTAKA}

Daniels, R., \& Nicoll, L. (2012). Contemporary Medical Surgical Nursing (2nd ed.). Clifton Park: Delmar, Cengage Learning.

Smeltzer, S. C., Hinkle, J. L., Bare, B. G., \& Cheever, K. H. (2010). Brunner \& Suddarth's textbook of medical-surgical nursing (12th ed., p. 1828). Philadelphia: Lippincott Williams \& Wilkins.

Timby, B. K., \& Smith, N. E. (2010). Introductory Medical Surgical Nursing (10th ed.). 2010: Lippincott Williams \& Wilkins.

Tortora, G. J., \& Derrickson, B. (2014). Principles Of Anatomy and Phisiology (14th ed., p. 400). Hoboken USA: Wiley.

White, L., Duncan, G., \& Baumle, W. (2013). Medical-Surgical Nursing: An Integrated Approach (3rd ed.). Clifton Park, USA: Delmar, Cengage Learning. 